\title{
Agronomic potential of four rock powders, pure or mixed, as soil remineralizers
}

\author{
Potencial agronômico de quatro pós de rocha, puros ou misturados, como remineralizadores de solos \\ Potencial agronómico de cuatro polvos de roca, puros o mezclados, como remineralizantes del suelo
}

\begin{abstract}
Detailed knowledge of chemical, petrographic and mineralogical compositions as well as the effects of applying rock powder on soil chemical properties and plant production are required for classifying these materials as soil remineralizers (SR), as according to Brazilian legislation in force. This study aimed to evaluate the potential of rock powders siltstone, tephrite and olivine melilitite, pure or mixed, on improving the fertility of a Cambisol and a Nitisol as well as the yield of soybean and barley crops grown in succession inside a greenhouse. For that purpose, these products were characterized as their granulometry, chemical, mineralogical and petrographic compositions. Based on the results, it was verified which products met the requirements for registration as SR established by the Normative Instruction Number 5 (NI5) from MAPA. Elemental chemical and grain size analyses indicated that all tested products met the NI5 requirements for their registration as SR. The mineral composition identified through petrographic analyses was confirmed by analyses performed via X-ray diffractometry techniques. Olivine melilitite rock, pure or mixed with siltstone, had the highest agronomic potential when compared to other powders, thus acknowledged as a SR. Although tephrite had little agronomic response on evaluated soils and crops, it also meets the SR requirements. Siltstone fulfilled most of NI5 criteria, except for exceeding the maximum content of free silica (quartz); therefore, it likely does not meet the requirements for its admittance as a SR.
\end{abstract}

Keywords: Granulometry; Petrography; Mineralogy; Elemental chemistry; NI5; Soil fertility; Plant production.

\section{Resumo}

O conhecimento pormenorizado da composição química, petrográfica, mineralógica e dos efeitos da aplicação de pós de rocha sobre as propriedades químicas do solo e na produção de plantas é exigido para o enquadramento desses materiais como remineralizadores de solos (RMS), segundo a legislação brasileira. Este estudo objetivou avaliar o potencial dos pós das rochas siltito, tefrito e olivina melilitito, puras ou em misturas, na melhoria da fertilidade de um Cambissolo e de um Nitossolo e na produtividade da soja e da cevada cultivadas em sucessão, em casa de vegetação. Para tanto, os produtos foram caracterizados quanto à sua granulometria, composição química, mineralógica e petrográfica. Com base nesses resultados, verificou-se quais desses produtos atenderam aos requisitos da Instrução Normativa número 5 (IN5), do MAPA, para registro como RMS. As análises químicas elementares e da granulometria indicaram que todos os produtos testados atenderam ao estabelecido na IN5, para registro como RMS. A composição mineral identificada nas análises petrográficas foi confirmada pelas análises realizadas por técnicas de difratometria de raios-X. A rocha olivina melilitito pura ou combinada com siltito teve o maior potencial agronômico quando comparada com os demais pós, podendo ser, portanto, admitida como RMS. O tefrito, embora tenha tido pouca resposta agronômica nos solos e nas culturas avaliados, também atende os requisitos para RMS. O siltito se enquadrou na maioria dos quesitos estabelecidos pela IN5, exceto por exceder o conteúdo máximo de sílica livre (quartzo), portanto, é provável que ela não atenda aos requisitos para enquadramento como RMS.

Palavras-chave: Granulometria; Petrografia; Mineralogia; Química elementar; IN5; Fertilidade de solos; Produção de plantas.

\section{Resumen}

El conocimiento detallado de la composición química, petrográfica y mineralógica y los efectos de la aplicación del polvo de roca en las propiedades químicas del suelo y en la producción de plantas son necesarios para la clasificación de estos materiales como remineralizantes del suelo (RS), según la legislación brasileña. Este estudio tuvo como objetivo evaluar el potencial del polvo de las rocas siltito, tefrito y olivina melilitito, puras o en mezclas, en la mejora de la fertilidad de un Cambissolo y un Nitossolo y en la productividad de la soja y la cebada cultivadas en sucesión, en casa de vegetación. Para ello, se caracterizaron los productos en cuanto a su granulometría, composición química, 
mineralógica y petrográfica. A partir de estos resultados, se verificó cuáles de estos productos cumplían los requisitos de la Instrucción Normativa número 5 (IN5), del MAPA, para su registro como RS. Los análisis químicos elementales y la granulometría indicaron que todos los productos probados cumplían los requisitos establecidos en la IN5, para su registro como RS. La composición mineral identificada en los análisis petrográficos fue confirmada por los análisis realizados mediante técnicas de difratometria de rayos-X. La roca de olivina melilitito, pura o combinada con siltito presentó mayor potencial agronómico en comparación con los otros polvos, por lo que puede ser admitida como RS. La tefrito, aunque tuvo poca respuesta agronómica en los suelos y cultivos evaluados, también cumple con los requisitos del RS. La siltito cumplía la mayor parte de los requisitos establecidos por el IN5, excepto la superación del contenido máximo de sílice libre (cuarzo), por lo que es probable que no cumpla los requisitos para su clasificación como RS.

Palabras clave: Granulometría; Petrografía; Mineralogía; Química elemental; IN5; Fertilidad del suelo; Producción vegetal.

\section{Introduction}

Today, the use of rock powder in agriculture has been significantly increasing in Brazil, mainly on organic, alternative, or non-conventional agriculture procedures (Manning \& Theodoro, 2020; Ramos et al., 2020). These mentioned production systems have restrictions on using soluble fertilizers yet allow using rock powders as nutrient sources, silicates included. Using these products aims to improve physical and chemical soil characteristics, minimizing environmental pollution as well as to ensure satisfactory yield for main agricultural crops (Manning \& Theodoro, 2020; Ramos et al., 2019; Basak et al., 2020; Theodoro et al., 2020; Ramos et al., 2020).

However, most silicate rocks may contain some essential nutrients in concentrations that are either very low or insufficient in meeting plant demand, as the case of potassium in some rocks (Martins et al., 2015; Basak et al., 2017; Nogueira et al., 2021). When facing these situations, an alternative is mixing two or more rock powders, increasing concentrations of the nutrient of interest in the final mixed composition.

This research was conducted in the region of Lages, Santa Catarina, where a wide variety of rocks rich in nutrients occur, such as some siltstones, phonolites, porphyritic phonolites, nepheline syenites, trachytes, tephrites and olivine melilitite, among others (Duarte et al., 2013, Martins et al., 2015; Longo et al., 2021; Nogueira et al., 2021). Despite the great diversity of these rocks, many of them have been little studied, lacking studies on their elemental, mineralogical and petrographic chemical composition, as well as their agronomic potential in providing improved soil fertility and plant yield, with the purpose of classifying them as soil remineralizers (SR) and to later use them as raw material for producing agrominerals employed in agriculture.

SR are defined as mineral-originate materials that only had their sizes reduced by mechanical processes, capable of changing soil fertility by adding nutrients to plants, providing improved growth and yield, and promoting improved physical or physical-chemical properties or even biological activity of the soil, as according to the Ministry of Agriculture, Livestock and Supply (MAPA, 2016). When these materials meet a set of legal requirements (Normative Instruction Number 5; NI5) established by the MAPA (2016), they can be enlisted in the fertilizer category and referred as SR.

With this in mind, studies previously developed by Ferreira et al. (2009), Duarte et al. (2013), Martins et al. (2015), Souza et al. (2017), Tavares et al. (2018), Pereira et al. (2019), Pereira et al. (2020), Junior et al. (2020), Marques et al. (2020), Theodoro et al. (2020), Marchi et al. (2020) and Nogueira et al. (2021), all with rock powder, pure or mixed, associated or not with manure (products that were similar or not to those tested in this study), respectively demonstrated improved fertility and yield of soil and plants subjected to rocking, presenting satisfactory performance in productivity terms, when compared to those subjected to conventional fertilization. According to these authors, this behavior is probably due to the release of macro and micronutrients contained within the rock powder, which may be even enhanced when combined with organic sources. Even though these studies reported the benefits of these products for soils and plants alike, they did not assess their possible 
classification as SR.

In light of the foregoing, this study aimed to characterize in detail the main chemical, physical, mineralogical and petrographic characteristics of four rock powders, as well as to evaluate their agronomic potential in providing improvements to the fertility of two soils with distinct physical-chemical characteristics and to the yield of soybean and barley crops grown in succession. Furthermore, it also aimed to evaluate the possible classification of these products as SR, in accordance to Brazilian legislation in force.

\section{Methodology}

Rock powders tested in this study were siltstone, tephrite, olivine melilitite and mixed siltstone + melilitite (1:1). Dinamisa Mineração S.A. supplied these products, already in powder form and with diameter of less than $0.3 \mathrm{~mm}$.

Samples from the powder of each rock were used for granulometric analysis, as proposed by the NI5 (MAPA, 2016). In short, samples were dried in a forced-circulation oven at the temperature of $100{ }^{\circ} \mathrm{C}$ for $48 \mathrm{~h}$, and then $100 \mathrm{~g}$ of each material was weighted and passed through a $0.30-\mathrm{mm}$-mesh sieve. Powder particles were separated from each rock by using an electromechanical shaker for $15 \mathrm{~min}$. Then, the material retained by the sieve was weighed and its percentages as well as those of the material that had passed through the sieve were calculated.

For chemical analyses, rock powders were passed through $0.25 \mathrm{~mm}$-mesh sieves in order to obtain the Filler granulometry. Afterwards, samples from each rock powder were ground with an agate mortar, put through a 0.053-mm-mesh sieve and analyzed as not pressed powder via X-ray Fluorescence (XRF). Two grams of ground samples were used; they were packed in standard sample holders with the bottom lined with $3.6 \mu \mathrm{m}$ of "mylar" polyester film.

The equipment used for these analyses was a compact X-ray energy-dispersive spectrometer (EDX), model Epislon 3 from Panalytical. It was equipped with a maximum power generator at high voltage of $9000 \mathrm{~mW}$, voltage from 4 to $30 \mathrm{kV}$ and current intensity from 1 to $1000 \mu \mathrm{A}$, with the $\mathrm{X}$-ray tubes made of rhodium $(\mathrm{Rh})$ anode material, a $50-\mu \mathrm{m}$-thick beryllium window and Si-PIN diode detector with data processing by a multi-channel analyzer (MCA). Pressurized helium gas and electronic thermoelectric air-cooling (Peltier) power the system. Element quantification was by creating an application called OMNIAN, included in the Epsilon software package and calibrated from standard molten wafer samples.

Elemental chemical analyses (ECA) of major and minor elements from each rock were held also via chemical methods conducted at the internationally certified laboratory ALS Global, based in Vespasiano, MG. Analyses took place at the company head office in Peru, using several protocols and quantifying elements by Inductively Coupled Plasma (ICP-AES). Although several elements were evaluated, this study will only present results from XRF and ECA analyses of the elements in oxide form, namely: $\mathrm{Ca}^{2+}, \mathrm{Mg}^{2+}, \mathrm{K}^{+}, \mathrm{P}, \mathrm{Si}, \mathrm{Al}^{3+}$; and the potentially toxic elements: $\mathrm{As}, \mathrm{Cd}, \mathrm{Hg}$ and $\mathrm{Pb}$. ALS Global solely evaluated this latter group.

Mineralogical analyses of powders from siltstone, tephrite and olivine melilitite rocks were held by X-ray diffractometry (XRD) in a Philips diffractometer, model PW 3710, equipped with a copper tube, $\theta / 2 \theta$ compensation angle and a graphite monochromator, with angular variation from 3.2 to $42^{\circ} 2 \theta$. Angular speed was of $0.02^{\circ} 2 \theta / \mathrm{s}$, in step mode, with reading time of 1 (one) second per step. The diffractograms was made in the X Pert HighScore Plus program, version 3.0. Criteria employed for interpreting diffractograms and identifying minerals within the powder from these rocks were based on the interplanar spacing (d) and on the behavior of diffraction reflections as presented by Jackson (1965), Brindley and Brown (1980), Whittig and Allardice (1986) and complete tables containing peaks of several constant minerals from the following website: rruff.geo.arizona.edu/ref/Minerals_main.html.

$\mathrm{Ph} . \mathrm{D}$. Andrea Brum da Silva, a specialist in alkaline and ultrabasic rocks, conducted the petrographic analyses of the rocks. In short, the procedure was as it follows: samples were sawed to be $20 \times 40 \mathrm{~mm}$, glued on glass slides with industrial 
Araldite@, and then lowered to $0.3 \mathrm{~mm}$. A planar-polarized light microscope was used to identify the minerals on the thin section. Modal percentage was determined by 500-point counting, and rock classification based on Streckeisen (1978).

In order to evaluate the agronomic potential of these rock powders, pure or mixed, the study was conducted with samples from two soil types collected in the superficial horizon, at the depth from 0 to $20 \mathrm{~cm}$. One was a Cambisol along the highway SC 114 around Pinheiro Seco (Cambissolo Háplico Alumínico Típico (Embrapa, 2018), Cambisol) and the other was a Nitisol along the highway BR 282 at Amola Faca (Nitossolo Bruno Distroférrico Típico (Embrapa, 2018), Nitisol), both located within Lages municipality and collected from uncultivated areas.

After collection, the soils were air dried in the greenhouse, had their clods broken and put through a 4-mm-mesh sieve. For chemical analyses prior to incubation, samples were ground and passed through 2-mm-mesh sieves to obtain airdried fine soil (ADFS).

With ADFS, $\mathrm{pH}$ in water and in SMP were determined, both by potentiometry on the soil:solution ratio of $1: 1$. P and K+ were extracted with Melich-1 solution and quantified, respectively, by colorimetry (Murphy and Riley, 1962) and flame photometry (Tedesco et al., 1995). These analyses were performed for calculating soil requirements of lime and fertilization in the conventional treatment, respectively. Pot capacity (PC) was determined as described in Casaroli and Lier (2008). Prior to its incubation, the Cambisol had these following chemical characteristics: water $\mathrm{pH}$ of $4.64, \mathrm{SMP} \mathrm{pH}=4.93, \mathrm{P}^{2}=2.91 \mathrm{mg} \mathrm{kg}{ }^{-1}$, $\mathrm{K}=0.31 \mathrm{cmol}_{\mathrm{c}} \mathrm{kg}^{-1}$; and the Nitisol: water $\mathrm{pH}: 5.23, \mathrm{SMP} \mathrm{pH}=5.3, \mathrm{P}=1.21 \mathrm{mg} \mathrm{kg}^{-1}$ and $\mathrm{K}=0.13 \mathrm{cmol}_{\mathrm{c}} \mathrm{kg}^{-1}$.

Soil incubation took place in the greenhouse as it follows: treatments consisted of applying to the two soils increasing doses of powders from siltstone, tephrite, olivine melilitite and siltstone + olivine melilitite rocks, equivalent to 5 and $10 \mathrm{t}$ ha ${ }^{-1}$. In addition to these treatments, to each soil was added a control (soil in natural condition) and limestone (PRNT=90\%, $\mathrm{CaO}=29 \%, \mathrm{MgO}=19 \%$, filler granulometry, after a $0.25-\mathrm{mm}$-mesh sieving) corrected in order to reach $5.5 \mathrm{pH}$. During this step, only limestone was added to the corresponding treatments.

Each treatment had four repetitions and the doses were homogenized in $20 \mathrm{~kg}$ soil samples (dry base). Afterwards, distilled water was applied to raise moisture to $80 \%$ of the PC. In sequence, samples were packed in $50 \mathrm{~L}$ plastic bags protected by a raffia bag. These in turn were open every 10 days to homogenize the samples and, when necessary, to replace the humidity with deionized water. This step lasted 45 days.

After incubation, $20 \mathrm{~kg}$ of soil (dry basis) of each treatment making up the four repetitions were homogenized once again and $140 \mathrm{~g}$ (wet soil) was collected for chemical analyses. Subsequently, those subjected to conventional fertilization were then fertilized with $\mathrm{P}$ and $\mathrm{K}^{+}$by using triple superphosphate (SFT) and $\mathrm{KCl}$, respectively. Urea was not used as the soybean was inoculated. The Commission of Chemistry and Soil Fertility of the States of Rio Grande do Sul and Santa Catarina (CQFS-RS/SC, 2016) recommended fertilizations with $\mathrm{P}$ and $\mathrm{K}^{+}$for the soybean crop, based on results from chemical analyses prior to soil incubation. Fertilizer calculations for this crop predicted a yield of $3 \mathrm{t} \mathrm{ha}^{-1}$ grains.

The experiment was conducted in a greenhouse by using $7 \mathrm{~L}$ buckets with $5 \mathrm{~kg}$ of soil (dry base) over 127 days, between January and May 2019. In each bucket (experimental unit), eight seeds were sown (soybean; cultivar BRS 232) without pre-germination, and after four thinning ( 1 plant every 10 days), only one plant was left per vessel until the cycle ended. Soils were kept with moisture close to $80 \%$ of the PC by daily weighing the buckets and by replenishing moisture with deionized water. The experimental design employed was in randomized blocks, having 19 treatments with four repetitions in two soils (two experiments with 76 experimental units).

At the end of the soybean experiment, plant and soil samples were collected from each experimental unit. Soils were homogenized again after collecting the roots, then stored in their respective buckets and kept at $80 \%$ PC over 30 days. Subsequently, barley (cultivar ANAG 03) was grown in succession with the same treatments and soils used previously for soybean. Before setting the experiment up, only soils corresponding to the conventional treatment were fertilized once again 
with $\mathrm{P}$ and $\mathrm{K}^{+}$, as established by the CQFS-RS/SC (2016). Cambisol and Nitisol presented, respectively, the following $\mathrm{P}$ and $\mathrm{K}^{+}$contents after the soybean cultivation in this same treatment: $\mathrm{P}=13.80 \mathrm{mg} \mathrm{kg}^{-1}$ and $\mathrm{K}^{+}=0.13 \mathrm{cmol}_{\mathrm{c} \mathrm{kg}} \mathrm{and}^{-1} \mathrm{P}=8.18 \mathrm{mg}$ $\mathrm{kg}^{-1}$ and $\mathrm{K}^{+}=0.10 \mathrm{cmol}_{\mathrm{c}} \mathrm{kg}^{-1}$. $\mathrm{P}$ and $\mathrm{K}^{+}$sources were the same as previously used. These soils were fertilized while aiming at the yield of $5 \mathrm{tha}^{-1}$.

In each experimental unit, 12 seeds were sown without pre-germination and only five plants were left after thinning (1 plant every 10 days). Soil moisture and experimental design was as described above for the soybean crop.

$\mathrm{N}$ was applied in all treatments ten days after plant emergence at a dose of $100 \mathrm{~kg} \mathrm{ha}^{-1}$ (50 ppm) by using urea as source. However, urea was not applied after plants were harvested in the Cambisol subjected to the control and to the powders from siltstone, tephrite and siltstone + olivine melilitite rocks at a dose equivalent to $5 \mathrm{t} \mathrm{ha}^{-1}$, and in the Nitisol, only in the control and with siltstone rock powder treatments at the two tested doses. This occurred because plants were senescing in these said treatments. Shoots and roots were collected in advance during the flowering period (Embrapa, 2009), indicated by plants that have demonstrated they would survive until the end of the cycle. Urea was applied until the seed filling stage in other treatments that plants went on until the end of the cycle.

Plants were collected at the end of the experiments. For soybean, the pods, leaves, and stems were collected from each experimental unit, stored in paper bags, and dried in a forced-circulation oven at temperature of $60{ }^{\circ} \mathrm{C}$ until reaching constant weight. After being manually separated from the soils, the roots were washed under running water and dried as previously described. For barley, the ears, stem + leaves, and roots were all collected separately on plants that remained until the end of the cycle. Sample processing was as previously reported for the soybean crop.

Production of the two evaluated plants was obtained as it follows: 1) manual counting of the number of pods (NP), ears (NE) and seeds (NS); 2) weight of seeds (WS) and; 3) of the shoot and roots to obtain the dry weights of shoot (SDW) and roots (RDW), respectively. Summing these two resulted in total dry weight (TDW). Only data referring to TDW, NP and NE and NS is used in this study.

For soil chemical analyses, after conducting these two experiments described above and separating the soil-root set, $140 \mathrm{~g}$ of wet soil was collected from each experimental unit. Then, in order to obtain the ADFS, samples were dried in an oven at $60{ }^{\circ} \mathrm{C}$ for $24 \mathrm{~h}$, ground and lastly passed through 2-mm-mesh sieves.

With the ADFS, the water $\mathrm{pH}$ was determined by potentiometry at a soil:solution ratio of $1: 1$, as well as the exchangeable $\mathrm{Ca}^{2+}, \mathrm{Mg}^{2+}$, and $\mathrm{Al}^{3+}$ contents at a soil:solution ratio of $1: 10$ after extraction with a $1 \mathrm{~mol} \mathrm{~L}^{-1} \mathrm{KCl}$ solution (Embrapa, 2017). Quantification of $\mathrm{Ca}^{2+}$ and $\mathrm{Mg}^{2+}$ was via atomic absorption spectrophotometry (Tedesco et al., 1995) and of $\mathrm{Al}^{3+}$ was by titration with $\mathrm{NaOH} 0.02 \mathrm{~mol} \mathrm{~L}^{-1}$ in $20 \mathrm{~mL}$ of the extract. $\mathrm{P}, \mathrm{K}^{+}$and $\mathrm{Na}^{+}$were extracted with Melich-1 solution (Tedesco et al., 1995), with the former quantified by colorimetry (Murphy and Riley, 1962) and the latter two by flame photometry. From these results, other soil chemical attributes were calculated. Nevertheless, only $\mathrm{Ca}^{2+}, \mathrm{Mg}^{2+}$ and $\mathrm{Al}^{3+}, \mathrm{P}, \mathrm{K}^{+}$ and the sum of bases is presented and discussed in this study.

Soil and plant data were subjected to the analysis of variance (5\% probability of error) by using the Sisvar 5.6 program (Ferreira, 2014). For soil results, when significant, the Scott-Knott test was applied. For plants, means were compared using the $\mathrm{F}$ test for orthogonal contrasts.

\section{Results and Discussion}

\subsection{Rock analyses}

Granulometric analyses indicated that all rock powders tested in this study met the legislation established by the NI5, hence classifying them as filler (Table 1). 
Table 1. Granulometric analysis of tested materials.

\begin{tabular}{|c|c|c|c|c|}
\hline Rocks & Sieve & $\begin{array}{l}\text { Physical nature } \\
\text { specification }\end{array}$ & Passing Particles & $\mathrm{NI}^{(1)}$ \\
\hline & \multicolumn{2}{|r|}{ 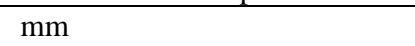 } & \multicolumn{2}{|c|}{$\%$} \\
\hline O. Meli. & & & 100 & 100 \\
\hline Siltstone & 0.3 & Filler & 99 & $*$ \\
\hline Tephrite & & & 99 & $*$ \\
\hline Silt. + O. Meli. & & & 99 & * \\
\hline
\end{tabular}

XRF results for the olivine melilitite rock shown low $\mathrm{SiO}_{2}$ contents (ultrabasic rock), very high $\mathrm{CaO}$ and $\mathrm{MgO}$ contents, and high $\mathrm{K}_{2} \mathrm{O}$ contents. On the other hand, high $\mathrm{SiO}_{2}$ content was recorded for siltstone, which is compatible with this rock type as it is more siliceous. This rock has relatively high $\mathrm{CaO}$ and $\mathrm{MgO}$ contents as well as high $\mathrm{K}_{2} \mathrm{O}$ content. As for the tephrite, elemental chemical analyses unveiled relatively high content of both $\mathrm{SiO}_{2}$ (basic rock group) and $\mathrm{CaO}$, low content of $\mathrm{MgO}$ and a very high $\mathrm{K}_{2} \mathrm{O}$ content. As for siltstone + olivine melilitite, the oxide content was approximately the mean from adding up individual values of the olivine melilitite, albeit still having high contents of $\mathrm{CaO}$ and $\mathrm{MgO}$ as well as $\mathrm{K}_{2} \mathrm{O}$ (Table 2). All powders had their content of potentially toxic elements ( $\mathrm{As}, \mathrm{Cd}, \mathrm{Hg}$ and $\mathrm{Pb}$ ) below limits (data not shown) established by the NI5.

Table 2. Chemical composition of rock powders obtained by X-ray fluorescence (XRF) and elemental chemical analysis (ALS Global).

\begin{tabular}{|c|c|c|c|c|c|c|c|}
\hline \multirow[b]{2}{*}{ Rocks } & \multicolumn{7}{|c|}{ XRF } \\
\hline & $\mathrm{CaO}$ & MgO & $\mathrm{K}_{2} \mathrm{O}$ & Sum & $\mathrm{P}_{2} \mathrm{O}_{5}$ & $\mathrm{SiO}_{2}$ & $\mathrm{Al}_{2} \mathrm{O}_{3}$ \\
\hline O. Meli. ${ }^{(1)}$ & 15.28 & 14.91 & 3.59 & 33.78 & 1.55 & 37.7 & 10.37 \\
\hline Tephrite & 6.72 & 1.36 & 5.69 & 13.77 & 0.99 & 50.09 & 21.06 \\
\hline \multirow{2}{*}{ Silt + O. Meli. ${ }^{(2)}$} & 11.99 & 10.65 & 3.69 & 26.33 & 1.31 & 45.62 & 12.05 \\
\hline & \multicolumn{7}{|c|}{ ALS Global (ICP) } \\
\hline Tephrite & 6.77 & 2.28 & 4.68 & 13.73 & 0.59 & 47.7 & 16.5 \\
\hline Silt + O. Meli. ${ }^{(2)}$ & 11.9 & 10.25 & 2.84 & 24.99 & 0.88 & 42.3 & 9.3 \\
\hline
\end{tabular}

(1) Olivine melilitite; ${ }^{(2)}$ Siltstone + Olivine melilitite. Source: Authors (2021).

In terms of elemental chemical analyses, classifying the rocks evaluated in this study as SR can be explained by the high content of basic cations within the chemical composition of each powder type tested. To that end, Brazilian legislation establishes that for considering these products as SR, they should present the following minimum specifications and insurances: base sum content equal to or greater than $9 \%$ and $\mathrm{K}_{2} \mathrm{O}$ content equal to or greater than $1 \%$ (Table 2). In addition, have relatively high contents of total phosphorus on pure powders from olivine melilitite and siltstone + olivine melilitite rocks ( $1.18 \%$ and $0.88 \% \mathrm{P}_{2} \mathrm{O}_{5}$, respectively) and lower contents of siltstone and tephrite $\left(0.29 \%\right.$ and $0.56 \% \mathrm{P}_{2} \mathrm{O}_{5}$, respectively) (Table 2), but that may contribute to the release of low phosphorus amounts to plants during the dissolution process of these rocks.

Petrographic analyses evidenced that olivine melilitite is a holocrystalline rock, having porphyritic texture and hypidiomorphic phenocrysts from fine to coarse grains, ranging in size from 0.5 to $6.0 \mathrm{~mm}$, of randomly arranged olivine (24\%), monticellite (8\%), melilitite (16\%), cebolite (11\%) and clinopyroxene, surrounded by poikilitic phlogopite (21\%) and occasionally by a dark reddish-brown cryptocrystalline bedrock (a possible iddginsite). Accessory minerals are perovskite (8\%), apatite (traces) and opaques (possible magnetite or ilmenite due to magnetism in hand sample). It is part of the 
subvulcanic ultramafic igneous class.

Mineralogical analysis of this rock unveiled a mineral assemblage similar to that indicated by the petrographic analysis, also identifying characteristic reflections of melilitite, clinopyroxenes, olivines and phlogopites minerals. Small vermiculite amounts were also detected by XRD, indicating a possible transformation of the solid-state phlogopites to vermiculite. Reflections with low intensity (around 2.81A) also indicate the presence of small amounts of apatites in the rock (Figure 1), which is compatible with the relatively high P contents confirmed by elemental analyses (Table 2).

Figure 1. X-ray diffractogram of the studied olivine melilitite rock powder.

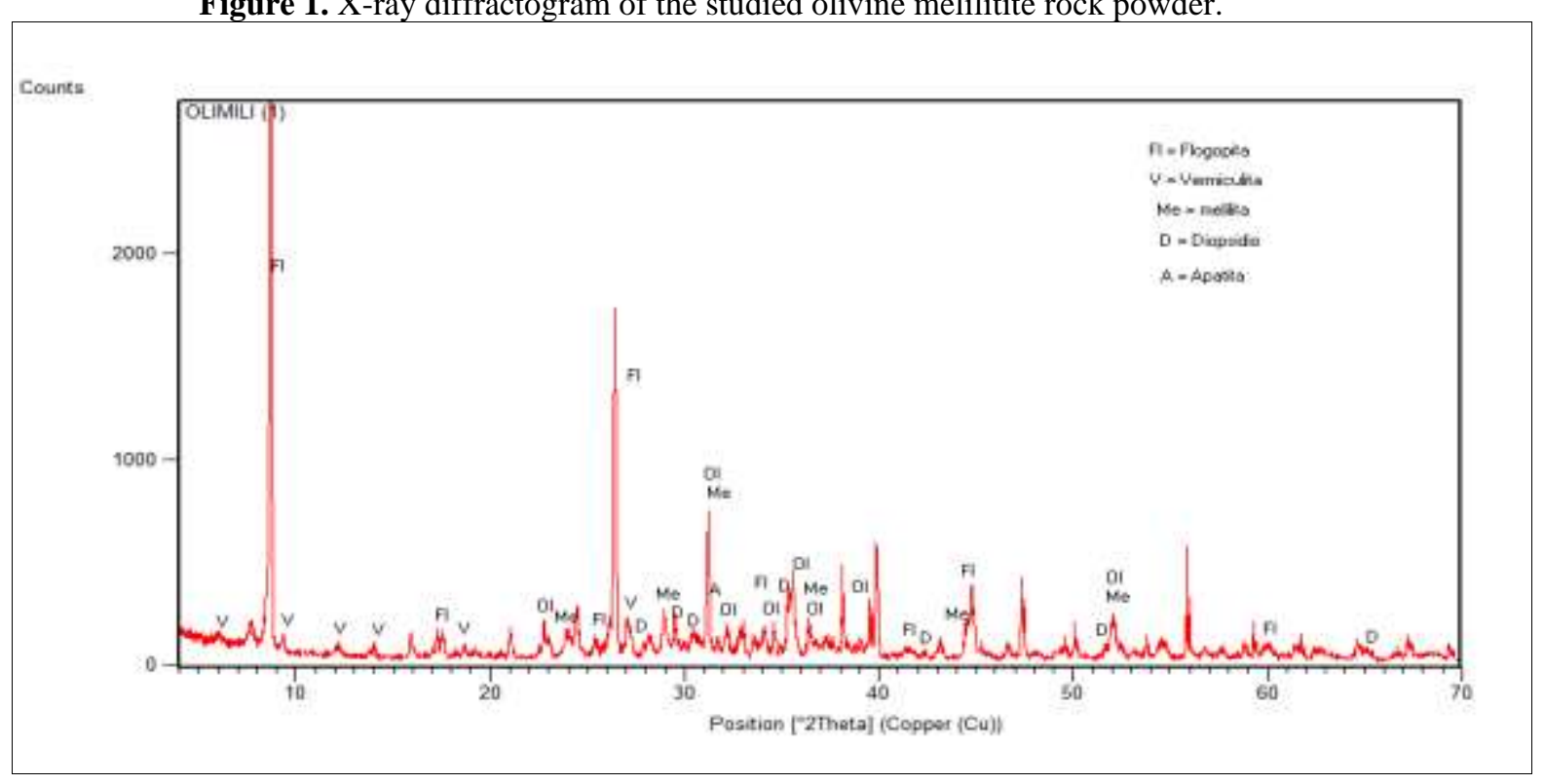

Source: Authors (2021).

Phlogopite had the highest intensity reflections in the diffractogram, which could indicate it as the dominant mineral in the sample. However, both chemical data and petrographic analysis indicated, respectively, relatively low amounts of $\mathrm{K}^{+}$yet a phlogopithite amount greater than $20 \%$. Therefore, the particles of this mineral must have gone through segregation and or orientation in the surface portion of the sample holder during the powder analysis. In any case, presence of relatively high amounts of phlogopite and apatite are uncommon features in olivine melilitites described under other environments (Dunworth \& Wilson, 1998; Renforth et al., 2015).

In quantitative values, olivine and melilitite when summed up were the most abundant minerals identified by the petrography, which is consistent with the intense peaks of these two minerals in the XRD (Figure 1). Minerals identified as diopside (pyroxene) were not confirmed by petrographic analysis, which in turn pointed low amounts of clinopyroxenes from the aegirine-augite type, making up just $2 \%$ of the sample. Briefly, this rock is very promising as an agromineral for agronomic use considering its high capacity to supply $\mathrm{Mg}^{2+}$ by the olivine group, $\mathrm{Ca}^{2+}$ from melilitite and monticellite decomposition, and $\mathrm{K}^{+}$and $\mathrm{Mg}^{2+}$ from phlogopite. Furthermore, the presence of apatites, identified via petrography in very small crystals, makes this ultrabasic rock one of the most promising in releasing several nutrients, hence being able to be classified as a multinutrient SR as also verified by Duarte et al. (2013), considering its relatively high micronutrient content as well (data not shown).

When evaluating the mineralogy and petrography of an olivine melilitite collected in a southern African province, Janney et al. (2002), found the dominant presence of phenocrysts and other important minerals such as melilitite, nepheline, clinopyroxene, phlogopite and perovskite, respectively, in this decreasing order of abundance. These authors also reported the 
presence of monticellite, zeolite and calcite.

A petrographic analysis of siltstone was not possible due to the difficulty in collecting its samples from healthy rocks, as it is occurs intermediated within ventings of the rock previously classified as phonotextile. The siltstone rock had an expressive alteration degree, easily fragmenting after drying, which made impregnating a suitable slide for observation impossible. Even though the petrographic analysis was not possible, this rock was still selected due to its expressive content of basic cations, $\mathrm{P}$, sulfur and $\mathrm{K}^{+}$revealed via chemical analysis, and because it was possible to visually observe micas, a possible $\mathrm{K}^{+}$source.

Quartz was the most abundant mineral identified by XRD in siltstone, with characteristic peaks around 0.424 and $0.334 \mathrm{~nm}$, which may be a preponderant factor for not classifying this rock as SR, as this high quartz content identified possibly must exceed the maximum limit of $25 \%$ of free silica in volume. Other minerals of note, but with less intense peaks, were micas (around 1.00, 0.5 and $0.33 \mathrm{~nm}$ ) and vermiculites (peaks at 1.425 and $0.446 \mathrm{~nm}$ ). Several indicative peaks of the nepheline feldspathoid and the sanidine feldspar were also identified, besides some minerals from the pyroxene group. Kaolinite, pyrite and apatites were also identified yet having much lower reflection intensities (Figure 2). Faizo et al. (2019), when evaluating the mineral composition of a siltstone collected at the Guaicurus Formation (MS), verified mainly the presence of quartz, mica, illite and chlorite.

Figure 2. X-ray diffractogram of the studied siltstone rock powder. Mineral abbreviations displayed in the figure are as the following: $\mathrm{Ve}=$ vermiculite; $\mathrm{Mi}=$ Mica; $\mathrm{Ap}=$ Apatite; $\mathrm{Ct}=$ Kaolinite; $\mathrm{Pi}=$ Pyrite; $\mathrm{Qt}=$ Quartz; $\mathrm{Sn}=$ Sanidine; $\mathrm{Nf}=$ Nepheline; $\mathrm{Px}=$ Pyroxenes, augite and aegerines.

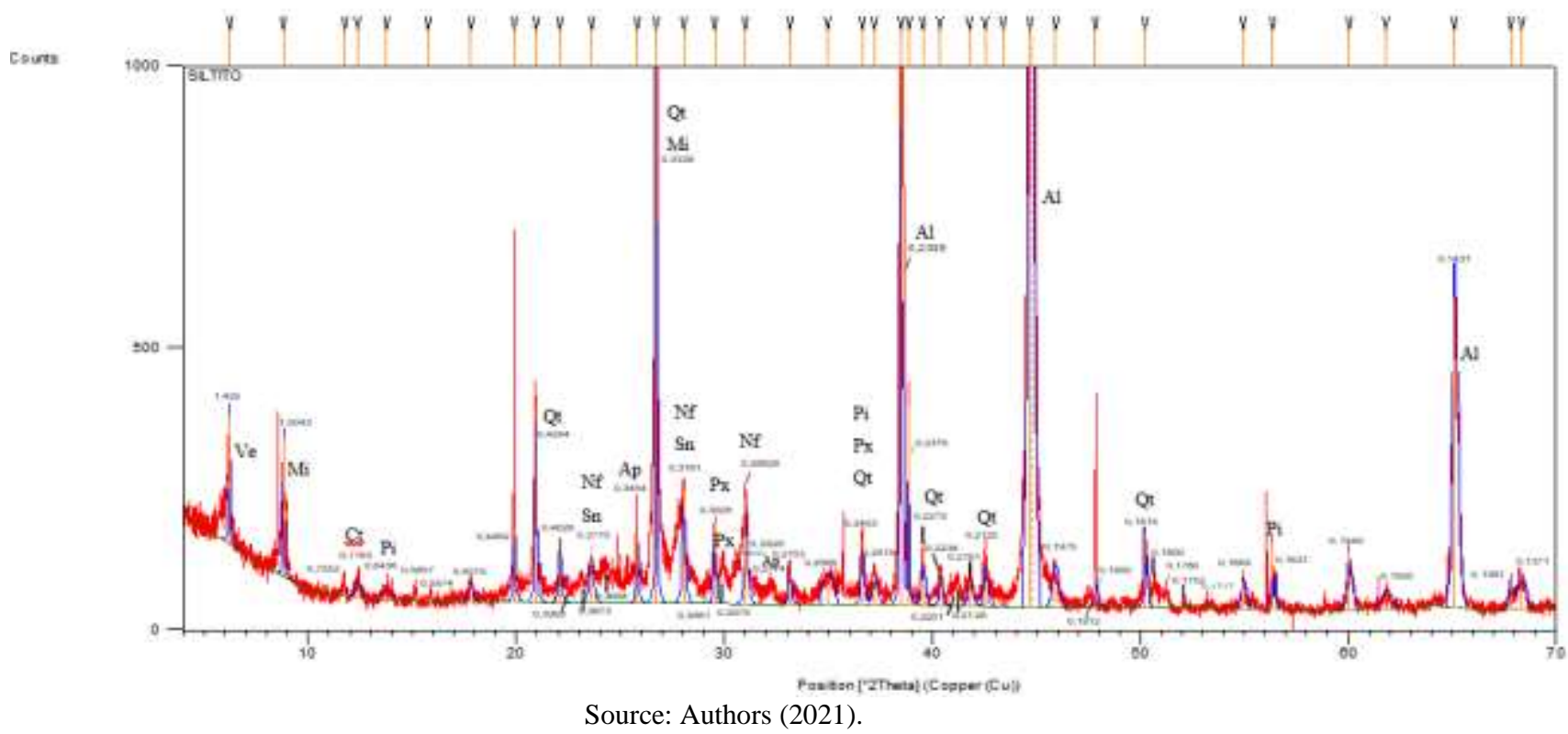

These results are compatible with the mineralogy of some fine-grained sedimentary rocks such as siltstones, which are pelitic rocks and usually composed by a mix of fine quartz associated to phyllosilicates (mica, vermiculite and kaolinite). However, they differ from the modal pattern by occurrence of other minerals such as feldspars, feldspathoids, pyroxenes, pyrites, and apatites. As these siltstone deposits are disseminated among magma vents that originated the phonotefrite, it is suggested that the original siltstone, probably from the Rio do Rasto Formation, went through paragenesis with incorporation of minerals from the tephritic magma.

The assemblage of minerals found in siltstone (Figure 2) demonstrates interesting characteristics from an agronomic 
perspective, having potential to be used as a rock powder for agriculture. This material presents an expressive content of basic cations $\left(\mathrm{Ca}^{2+}, \mathrm{Mg}^{2+}\right.$ and $\mathrm{K}^{+}$), high $\mathrm{K}^{+}$contents when compared to basalts, for instance, considerable $\mathrm{P}_{2} \mathrm{O}_{5}$ contents, and may constitute an important source of these nutrients for plants, as also verified by Fazio et al. (2019). Moreover, the high sulfur content stands out as the highest one among tested rocks, which comes from the pyrite presence (Figure 2).

As for tephrite, the petrographic analysis demonstrated that it has a massive structure, with porphyritic texture, and prismatic phenocrysts of alkali feldspar and pyroxene sized between 2.5 and $5.0 \mathrm{~mm}$. Its bedrock is mostly constituted by cryptocrystalline domains, in which individualizing and recognizing the minerals via microscopy was not possible. In the crystalline portions, which are restricted to the bedrock, it was possible to identify alkali feldspar, pyroxene, titanite, feldspathoids, apatite and opaques, having fine to medium size grains (between 0.3 and $2.0 \mathrm{~mm}$ ). Sanidine and pyroxene phenocrysts occupy approximately $29 \%$; bedrocks occupies $40 \%$; and opaques make for $31 \%$ of the total lamina. Presence of phenocrysts in a fine to microcrystalline bedrock suggests that the rock is basic and from volcanic to subvolcanic origins. Preliminarily, the classification was held as according to the QAPF diagram (Streckeisen, 1978), by using absence of quartz and presence of alkali feldspar and feldspathoids as criteria. That way, it is suggested to classify the rock as within the phonolites/tephrites field.

As in the petrography, mineralogical analyses of the tephrite bespoke the nepheline feldspathoid and the sanidine feldspar as the most abundant presences (Figure 3), both minerals serving as natural $\mathrm{K}^{+}$sources and having low weathering resistance. In order of abundance, next were minerals from pyroxene group, identifying the position of peaks from either augite or aegirine-augite. Such minerals are important sources of $\mathrm{Ca}^{2+}, \mathrm{Mg}^{2+}$ and/or Fe for soils and are considered as easily weathered within the silicates. Low-intensity apatite peaks were verified, confirming the petrographic analysis. Titanite was not identified by the XRD albeit confirmed by petrography, possibly due to its low amounts within the sample.

XRD also confirmed the presence of micas in small quantities, peaking around 1.0; 0.5 and $0.33 \mathrm{~nm}$. Peaks around 0.560; 0.343; and $0.292 \mathrm{~nm}$ also allowed identifying the mineral analcime (or analcite), a tectosilicate rich in $\mathrm{Na}$ from the zeolites group. Besides these, there were also expressive peaks at $0.651 ; 0.588$; and $0.438 \mathrm{~nm}$, which were tentatively identified as rhodesite, a rare-occurring mineral of fibrous habit with possible occurrence in basic and alkaline magmatic rocks. Finally, peaks at 0.484 and $0.436 \mathrm{~nm}$ allowed identifying the gibbsite (Figure 3), an aluminum hydroxide probably formed by alteration of the primary minerals from this rock.

Gibbsite presence was also identified within horizons and the soil saprolite derived from this same rock (Longo et al., 2021). Absence of these four minerals in the petrography may have been due to the difficulties of their slide observation, because most of this rock volume is constituted by a cryptocrystalline bedrock, where identifying minerals by optical methods used was not possible. 
Figure 3. X-ray diffractogram of the studied tephrite rock powder. Mineral abbreviations displayed in the figure are as the following: $\mathrm{Mi}=$ Mica, phyllosilicate, probably phlogopite; Ro = Rhodesite, fibrous phyllosilicate; $\mathrm{Ac}=$ Analcime, tectosilicate; $\mathrm{Gb}=$ Gibbsite, aluminum hydroxide; $\mathrm{Nf}=$ Nepheline, feldspathoid; $\mathrm{Sn}=$ Sanidine, potassium feldspar; Ae-Ag = aegirine-augite, clinopyroxenes; Ap = Apatite, phosphate.

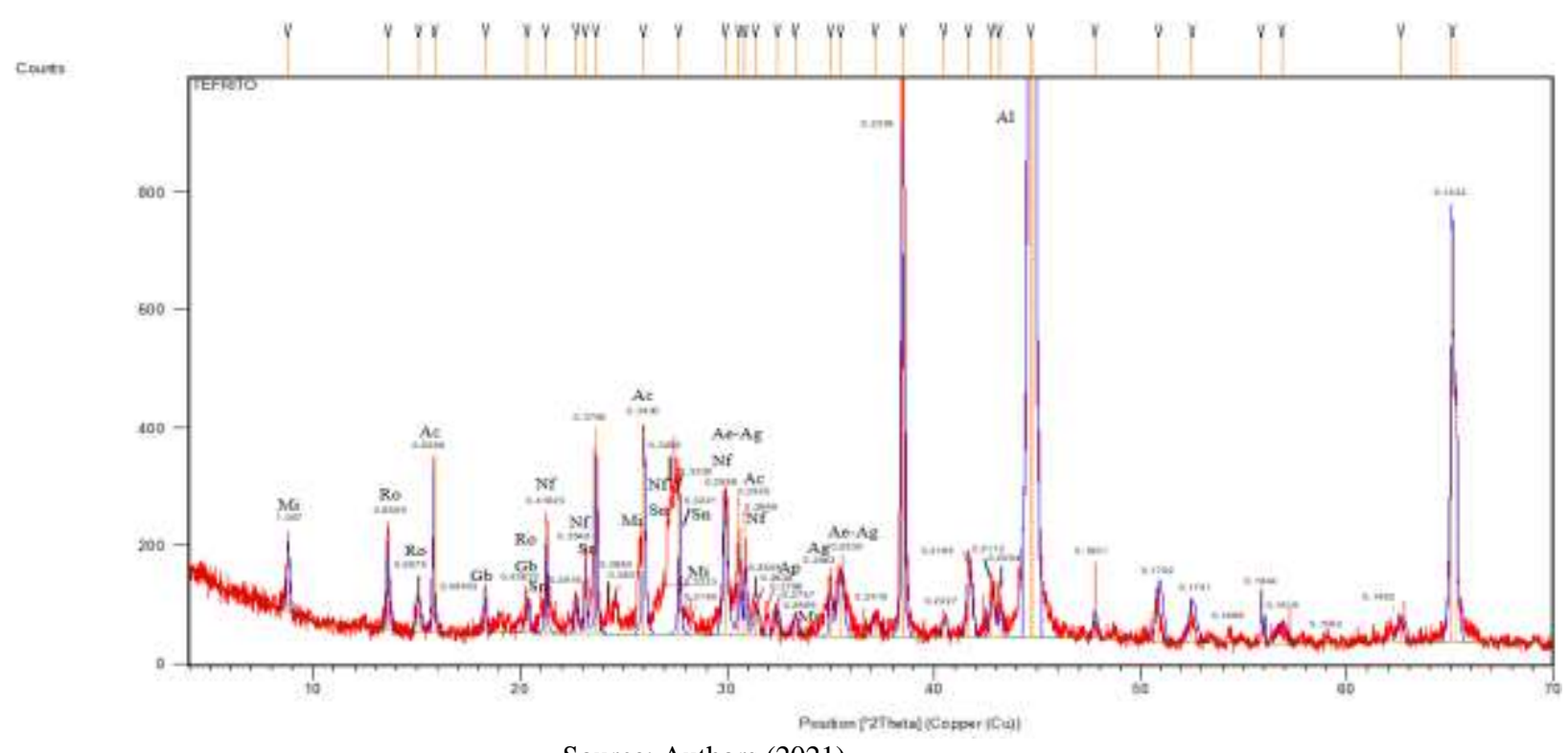

Source: Authors (2021).

\subsection{Agronomic potential of studied rocks}

\subsubsection{Soil chemical attributes}

Regardless of used soil, products, doses and crops, the pH values increased and differed statistically from the control. These results indicate that rock powders evaluated in this study were efficient, even if partially, in improving the fertility of the two soils used, notably in the Cambisol, which is a more buffered soil type than the Nitisol (Table 3 and Figure 4).

In most cases, $\mathrm{Al}^{3+}$ contents decreased when using products in their respective doses in relation to the control, after conducting the experiments in both soils. However, there was a slight reduction in $\mathrm{pH}$ values and a slight increase in $\mathrm{Al}^{3+}$ contents in most treatments after growing barley, although they differed statistically from the control (Table 3 and Figure 4).

Reduced $\mathrm{pH}$ and increased $\mathrm{Al}^{3+}$ contents after growing barley may be related to adding urea (Goulding, 2016) and possibly to the biodegradation of organic matter (OM) (notably in Cambisol) and subsequent organic acid release. This probably led to acidification of soils subjected to the different treatments, hence releasing high $\mathrm{H}^{+}$amounts and increasing their buffering (Lungu \& Dynoodt, 2008; Lu et al., 2015; Jiang et al., 2018). Moreover, it should be considered that high $\mathrm{Al}_{2} \mathrm{O}_{3}$ contents, mainly in the chemical composition of siltstone and tephrite, may have contributed to increased $\mathrm{Al}^{3+}$ contents in both soils and that it, consequently, increased or maintained their acidity (Tables 2 and 3, respectively). Studies conducted by Melo et al. (2012) and Alovisi et al. (2020a) support this interpretation. These authors found increased soil acidity with increasing incubation time, attributing this behavior to $\mathrm{OM}$ biodegradation and $\mathrm{Al}^{3+}$ release by solubilization of silicates after adding water.

$\mathrm{Ca}^{2+}$ and $\mathrm{Mg}^{2+}$ contents, regardless of the soil, doses of used products and tested crops, exceeded the control in most cases. However, $\mathrm{Ca}^{2+}$ contents in the two evaluated soils, except for the conventional treatment, were below the established as ideal by the CQFS-RS/SC (2016), which is $4-\mathrm{cmol}_{\mathrm{c}} \mathrm{kg}^{-1}$. On the other hand, concerning $\mathrm{Mg}^{2+}$ contents, in the Cambisol these were lower while for the Nitisol they were close to, and even exceeded, what is considered ideal by the abovementioned 
commission, which is $1-\mathrm{cmol}_{\mathrm{c}} \mathrm{kg}^{-1}$ in this case. In relation to the sum of $\mathrm{Ca}^{2+}$ and $\mathrm{Mg}^{2+}$, the contact time of the products with the soil favored rock decomposition and the subsequent release of these two nutrients, since there was an increase in their sum in both evaluated soils (except in the Cambisol cultivated with barley), close to and even exceeding 5-cmol $\mathrm{kg}^{-1}$ (Table 3).

Table 3. Soil chemical attributes post soybean and barley cultivations.

\begin{tabular}{|c|c|c|c|c|c|c|c|c|c|c|c|c|c|}
\hline & \multirow[b]{2}{*}{ Treatment } & \multicolumn{6}{|c|}{ Post soybean } & \multicolumn{6}{|c|}{ Post barley } \\
\hline & & Water pH & $\mathbf{A l}^{3+}$ & $\mathrm{Ca}^{2+}$ & $\mathrm{Mg}^{2+}$ & $\mathbf{K}^{+}$ & $\mathbf{P}$ & Water pH & $\mathbf{A l}^{3+}$ & $\mathrm{Ca}^{2+}$ & $\mathrm{Mg}^{2+}$ & $\mathbf{K}^{+}$ & $\mathbf{P}$ \\
\hline \multirow{11}{*}{ 己ֶ) } & & $1: 1$ & \multicolumn{4}{|c|}{ 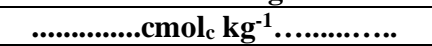 } & $\mathrm{mg} \mathrm{kg}^{-1}$ & & \multicolumn{4}{|c|}{................cmolc $\mathrm{kg}^{-1}$............... } & $\mathrm{mg} \mathrm{kg}^{-1}$ \\
\hline & Control & $4.57 \mathrm{e}$ & $4.73 a$ & $0.51 \mathrm{f}$ & $0.69 \mathrm{~d}$ & $0.27 \mathrm{~d}$ & $6.94 \mathrm{f}$ & $4.46 \mathrm{~d}$ & $3.92 \mathrm{a}$ & $0.32 \mathrm{~g}$ & $0.15 \mathrm{~h}$ & $0.37 \mathrm{a}$ & $6.10 \mathrm{~d}$ \\
\hline & Conv. & $5.61 \mathrm{a}$ & $0.19 \mathrm{~h}$ & $5.20 \mathrm{a}$ & $3.95 \mathrm{a}$ & $0.27 \mathrm{~d}$ & $8.89 \mathrm{e}$ & $5.76 \mathrm{a}$ & $0.43 \mathrm{~g}$ & $6.62 \mathrm{a}$ & $3.74 \mathrm{a}$ & $0.13 d$ & $13.80 \mathrm{a}$ \\
\hline & Silt. 5 & $4.85 \mathrm{~d}$ & $4.01 \mathrm{c}$ & $0.77 f$ & $0.70 \mathrm{~d}$ & $0.27 \mathrm{~d}$ & $9.98 f$ & $4.90 \mathrm{~b}$ & $3.77 b$ & $0.45 f$ & $0.57 f$ & $0.38 \mathrm{a}$ & $8.51 \mathrm{c}$ \\
\hline & Silt. 10 & $4.82 \mathrm{~d}$ & $3.89 \mathrm{c}$ & $0.98 \mathrm{e}$ & $0.80 \mathrm{c}$ & $0.26 \mathrm{~d}$ & $11.81 \mathrm{c}$ & $4.58 \mathrm{~d}$ & $3.91 \mathrm{a}$ & $0.53 f$ & $0.62 \mathrm{e}$ & $0.36 \mathrm{a}$ & $10.14 b$ \\
\hline & Teph. 5 & $4.76 \mathrm{~d}$ & $4.14 b$ & $0.60 \mathrm{~h}$ & $0.54 \mathrm{e}$ & $0.28 \mathrm{c}$ & $11.45 \mathrm{c}$ & $4.60 \mathrm{~d}$ & $3.62 \mathrm{c}$ & $0.37 \mathrm{~g}$ & $0.43 \mathrm{~g}$ & $0.22 b$ & $11.90 \mathrm{~b}$ \\
\hline & Teph. 10 & $4.82 \mathrm{~d}$ & $3.87 \mathrm{c}$ & $1.35 \mathrm{~d}$ & $0.55 \mathrm{e}$ & $0.27 \mathrm{~d}$ & $11.85 \mathrm{c}$ & $4.57 \mathrm{~d}$ & $3.83 a$ & $0.35 \mathrm{~g}$ & $0.40 \mathrm{~g}$ & $0.18 \mathrm{c}$ & $12.83 a$ \\
\hline & O. Meli. 5 & $5.04 \mathrm{~b}$ & $2.90 \mathrm{e}$ & $1.35 \mathrm{~d}$ & $0.85 \mathrm{c}$ & $0.31 b$ & $11.74 \mathrm{c}$ & $4.73 c$ & $3.13 \mathrm{e}$ & $0.64 \mathrm{e}$ & $0.76 \mathrm{~d}$ & $0.14 d$ & $10.79 b$ \\
\hline & O. Meli. 10 & $5.13 \mathrm{~b}$ & $1.75 \mathrm{~g}$ & $3.75 b$ & $0.99 b$ & $0.33 \mathrm{a}$ & $18.92 \mathrm{a}$ & $4.79 c$ & $2.48 \mathrm{f}$ & $1.29 \mathrm{c}$ & $0.94 b$ & $0.09 \mathrm{e}$ & $14.03 \mathrm{a}$ \\
\hline & Silt.+ O. Meli. 5 & $4.91 \mathrm{c}$ & $3.42 \mathrm{~d}$ & $0.69 f$ & $0.78 \mathrm{c}$ & $0.28 \mathrm{c}$ & $12.04 \mathrm{c}$ & $4.61 d$ & $3.42 \mathrm{~d}$ & $1.02 \mathrm{~d}$ & $0.66 \mathrm{e}$ & $0.12 \mathrm{e}$ & $10.93 b$ \\
\hline & Silt.+ O. Meli. 10 & $5.01 \mathrm{~b}$ & $2.63 f$ & $2.89 \mathrm{c}$ & $0.93 b$ & $0.29 \mathrm{c}$ & $15.69 \mathrm{~b}$ & $4.76 \mathrm{c}$ & $3.09 \mathrm{e}$ & $1.49 \mathrm{~b}$ & $0.89 \mathrm{c}$ & $0.11 \mathrm{e}$ & $13.44 \mathrm{a}$ \\
\hline \multirow{10}{*}{ 事 } & Control & $5.12 \mathrm{e}$ & $0.68 \mathrm{a}$ & $0.67 d$ & $1.24 \mathrm{e}$ & $0.15 \mathrm{f}$ & $1.46 \mathrm{e}$ & $4.84 b$ & $1.19 \mathrm{a}$ & $1.05 \mathrm{~g}$ & $0.95 \mathrm{e}$ & $0.16 a$ & $1.86 \mathrm{e}$ \\
\hline & Conv. & $6.29 \mathrm{a}$ & $0.05 \mathrm{~g}$ & $3.81 \mathrm{a}$ & $4.30 \mathrm{a}$ & $0.16 \mathrm{e}$ & $5.79 c$ & $5.73 a$ & $0.24 \mathrm{~g}$ & $5.96 a$ & $4.55 a$ & $0.10 \mathrm{c}$ & $8.18 \mathrm{a}$ \\
\hline & Silt. 5 & $5.54 \mathrm{~d}$ & $0.65 a$ & $1.99 \mathrm{c}$ & $1.44 \mathrm{~d}$ & $0.16 \mathrm{e}$ & $5.78 \mathrm{c}$ & $5.21 \mathrm{~b}$ & $1.03 \mathrm{c}$ & $2.91 \mathrm{~d}$ & $2.83 b$ & $0.16 \mathrm{a}$ & $2.37 \mathrm{~d}$ \\
\hline & Silt. 10 & $5.75 c$ & $0.52 b$ & $2.10 \mathrm{~b}$ & $1.67 \mathrm{c}$ & $0.16 \mathrm{e}$ & $6.23 b$ & $5.37 \mathrm{~b}$ & $1.03 \mathrm{c}$ & $3.33 \mathrm{c}$ & $2.89 b$ & $0.16 a$ & $3.86 \mathrm{c}$ \\
\hline & Teph. 5 & $5.68 \mathrm{~d}$ & $0.45 \mathrm{c}$ & $1.83 \mathrm{c}$ & $1.85 \mathrm{c}$ & $0.16 \mathrm{e}$ & $4.68 \mathrm{~d}$ & $5.15 b$ & $1.10 \mathrm{~b}$ & $2.10 \mathrm{f}$ & $2.60 \mathrm{c}$ & $0.15 \mathrm{a}$ & $3.24 \mathrm{c}$ \\
\hline & Teph. 10 & $5.63 \mathrm{~d}$ & $0.48 \mathrm{c}$ & $1.88 \mathrm{c}$ & $2.66 \mathrm{~b}$ & $0.18 \mathrm{c}$ & $4.86 \mathrm{~d}$ & $5.20 \mathrm{~b}$ & $1.07 \mathrm{~b}$ & $2.37 \mathrm{e}$ & $2.68 \mathrm{c}$ & $0.16 \mathrm{a}$ & $4.54 b$ \\
\hline & O. Meli. 5 & $5.75 \mathrm{c}$ & $0.20 \mathrm{e}$ & $2.04 \mathrm{~b}$ & $1.63 \mathrm{c}$ & $0.19 b$ & $5.03 \mathrm{~d}$ & $5.11 \mathrm{~b}$ & $0.86 \mathrm{~d}$ & $2.54 \mathrm{e}$ & $3.06 \mathrm{~b}$ & $0.10 \mathrm{c}$ & $2.67 \mathrm{~d}$ \\
\hline & O. Meli. 10 & $5.87 \mathrm{~b}$ & $0.18 \mathrm{f}$ & $2.12 b$ & $1.40 \mathrm{~d}$ & $0.21 \mathrm{a}$ & $7.16 \mathrm{a}$ & $5.18 b$ & $0.66 \mathrm{f}$ & $3.96 \mathrm{~b}$ & $2.63 \mathrm{c}$ & $0.12 b$ & $3.99 \mathrm{c}$ \\
\hline & Silt.+ O. Meli. 5 & $5.77 \mathrm{c}$ & $0.38 \mathrm{~d}$ & $1.97 \mathrm{c}$ & $1.55 \mathrm{~d}$ & $0.17 \mathrm{~d}$ & $5.79 \mathrm{c}$ & $5.16 b$ & $0.75 \mathrm{e}$ & $2.57 \mathrm{e}$ & $2.77 b$ & $0.12 b$ & $2.84 \mathrm{~d}$ \\
\hline & Silt.+ O. Meli. 10 & $5.76 \mathrm{c}$ & $0.22 \mathrm{e}$ & $2.19 \mathrm{~b}$ & $1.84 \mathrm{c}$ & $0.18 \mathrm{c}$ & $5.68 \mathrm{c}$ & $5.28 \mathrm{~b}$ & $0.72 \mathrm{e}$ & $3.97 \mathrm{~b}$ & $2.90 \mathrm{~b}$ & $0.10 \mathrm{c}$ & $3.87 \mathrm{c}$ \\
\hline
\end{tabular}

Conv. (Conventional); Silt. (Siltstone); Teph. (Tephrite); O. Meli. (Olivine Melilitite); Silt. + O. Meli. (Siltstone + Olivine Melilitite). Means followed by the same letter in the column do not differ by the Scott-Knott test at 5\%. Source: Authors (2021).

Still concerning $\mathrm{Ca}^{2+}$ and $\mathrm{Mg}^{2+}$ contents, it is important to highlight, besides the conventional treatment, the rock powder from olivine melilitite, be it pure or mixed with siltstone. Both its contents and sum of these mentioned nutrients in Cambisol, being even more pronounced in Nitisol, were close to and actually exceeded what is considered ideal by the CQFSRS/SC (2016) (Table 3). Results obtained with this rock are promising, since this is a low solubility product when compared to conventional fertilizers; yet even so, it was efficient both in promoting the increase of these nutrients to satisfactory levels in the two soils and in their fertility as well (Table 3). This is due to the higher solubility of this rock (Oelkers et al., 2018) and the high $\mathrm{CaO}$ and $\mathrm{MgO}$ contents (Table 2), which makes promising using it as a SR, as also verified by Duarte et al. (2013).

Siltstone and tephrite rocks, even though they only partially improved soil fertility during the short evaluation period (Table 2 and Figure 4), they also show promising potential for being used as remineralizers or mixing components, considering their relatively higher $\mathrm{K}^{+}$contents (Table 2) than olivine melilitite; however, they require more time to solubilize and release nutrients present in their minerals. Tephrite has a composition relatively similar to that of many basalts from Santa Catarina, although it has lower $\mathrm{MgO}$ contents, but with the advantage of having higher $\mathrm{K}_{2} \mathrm{O}$ and $\mathrm{P}_{2} \mathrm{O}_{5}$ contents than them (Table 2). As for siltstone, besides having high sums of $\mathrm{CaO}$ and $\mathrm{MgO}$ (Longo et al., 2021), it also stands out for its higher $\mathrm{K}_{2} \mathrm{O}$ contents than olivine melilitite, and for the sulfur presence in the pyrite form. This can be advantageous when adding this material mixed with other powders, as the pyrite oxidation can assist in the solubilization of other minerals present. 
Figure 4. Chemical attributes of soils after soybean and barley crops, conducted in the greenhouse on a Cambisol and a Nitisol.

\section{Cambisol}

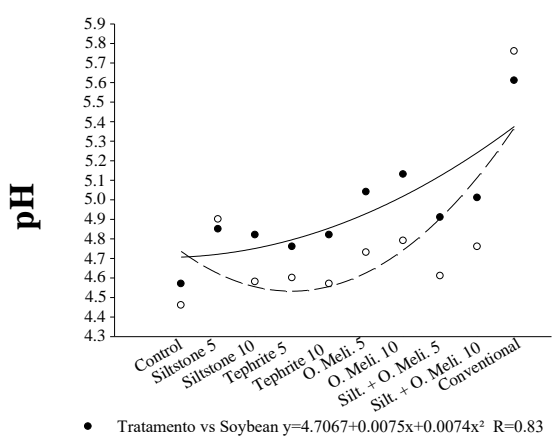

Tratamento vs Barley $y=4.7360+-0.1370 x+0.0230 x^{2} \quad R=0.75$
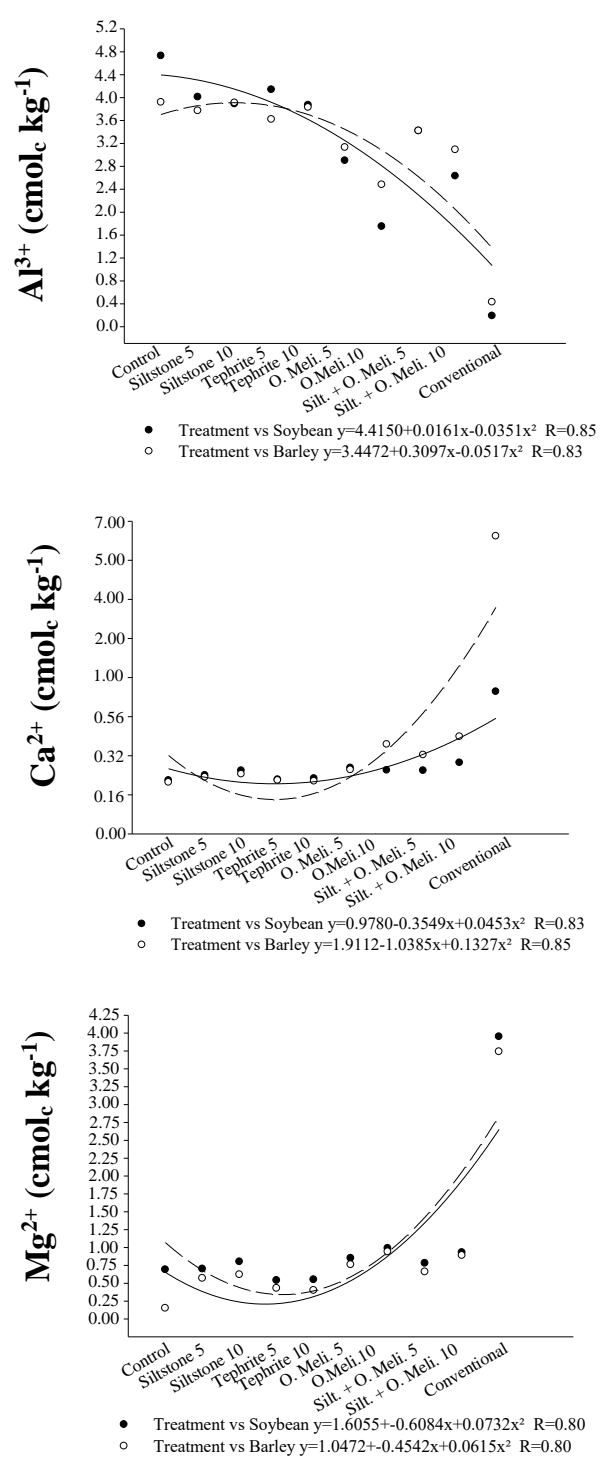

Nitisol

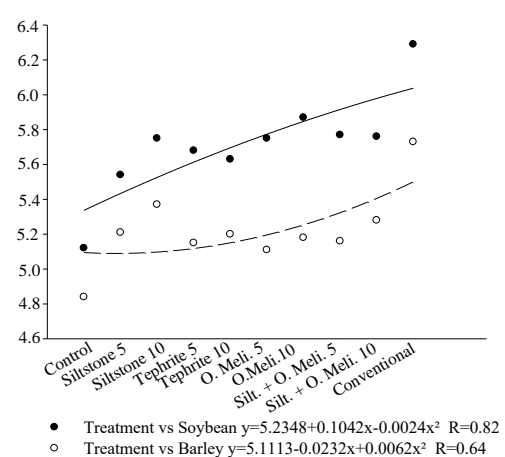

- Treatment vs Soybean $y=5.2348+0.1042 \mathrm{x}-0.0024 \mathrm{x}^{2} \quad \mathrm{R}=0.82$
Treatment vs Barley $\mathrm{y}=5.1113-0.0232 \mathrm{x}+0.0062 \mathrm{x}^{2} \quad \mathrm{R}=0.64$

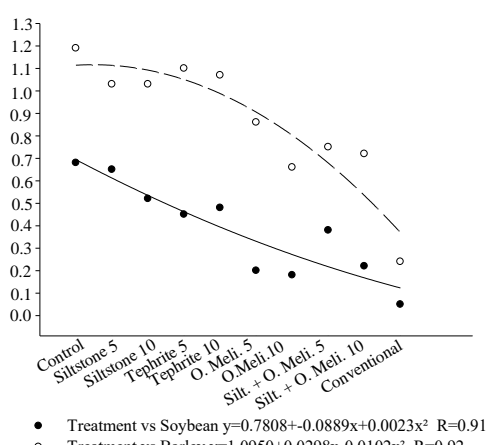

Treatment vs Soybean $\mathrm{y}=0.7808+-0.0889 \mathrm{x}+0.0023 \mathrm{x}^{2} \mathrm{R}=0.9$

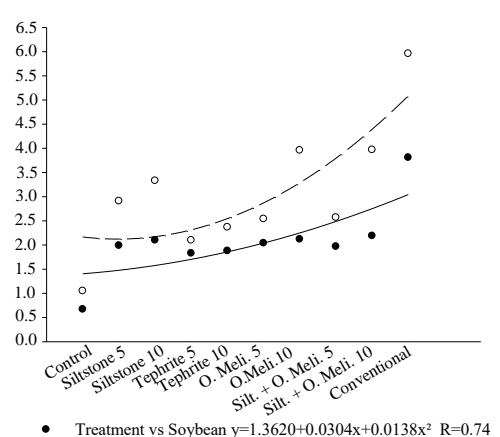

Treatment vs Soybean $\mathrm{y}=1.3620+0.0304 \mathrm{x}+0.0138 \mathrm{x}^{2} \quad \mathrm{R}=0.74$
Treatment vs Barley $\mathrm{y}=2.2990-0.1796 \mathrm{x}+0.0458 \mathrm{x}^{2} \quad \mathrm{R}=0.78$

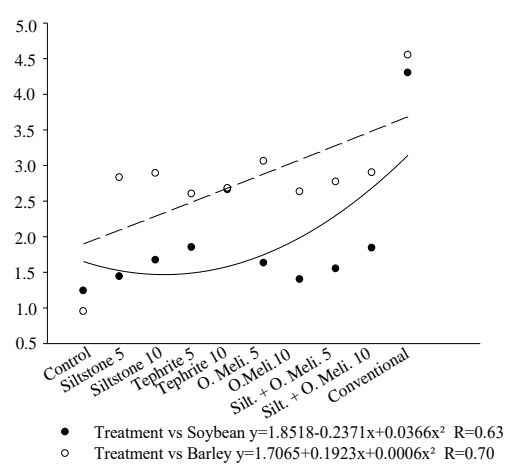



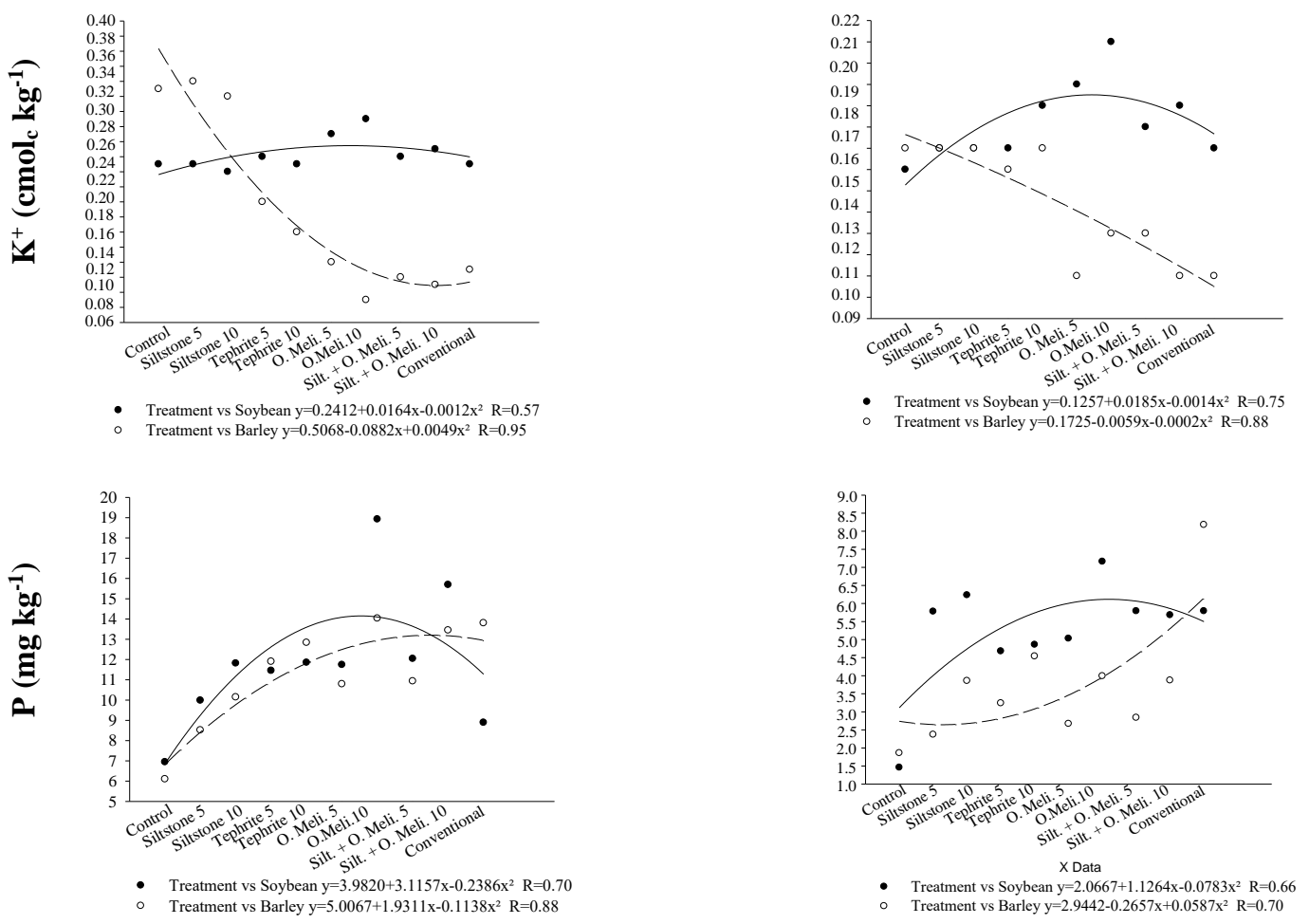

\section{Treatment $\left(\mathrm{t} \mathrm{ha}^{-1}\right)$}

Source: Authors (2021).

$\mathrm{K}^{+}$contents did not went through substantial changes, regardless of products, used doses and tested crops (Table 3 and Figure 1), even though tested rocks had high $\mathrm{K}_{2} \mathrm{O}$ contents in their chemical compositions (Table 2). This may indicate that the incubation time of the rocks may have been insufficient to increase this nutrient release or it may be related to its absorption by plants during the experiments. This nutrient is highly required by plants at their different growing stages and is used in the production of both TDW and seeds (Cunha et al., 2019; Nogueira et al., 2021). Even so, $\mathrm{K}^{+}$contents were characterized as "medium" and "high" in most treatments, according to the criteria established by the CQFS-RS/SC (2016), thus indicating that tested rock powders were effective in maintaining $\mathrm{K}^{+}$at adequate levels in the CEC of the soils (Table 3 and Figure 1).

Higher $\mathrm{P}$ contents evidenced in Cambisol may be related to the presence of apatites in the rocks, as evidenced in their mineralogical and petrographic analyses, promoting increased P during the experiments (Table 3 and Figure 1). Nevertheless, these results should be carefully interpreted, since a double-acid solution (Melich-1) was used for its extraction, which may have promoted the dissolution of $\mathrm{P}$ from fractions not available to plants. On the other hand, in the Nitisol, as it is a more clayey soil type, its low P content (Table 3 and Figure 1) may be related to its absorption by colloids of this soil (Alovisi et al., 2020b; Mumbach et al., 2020), or immediately absorbed by plants after its release.

\subsubsection{Soybean and barley plant production}

Products, tested doses and contact time of the products with both evaluated soils influenced the yield of soybean and barley plants. In most cases, the products were efficient in improving the production of TDW, NP and NS when compared to that obtained in the control treatments. The exception was in treatments with powders from siltstone and tephrite rocks, in which the yield of tested plants, in most cases, did not differ from the control (Table 4 and Figure5). 
Table 4. Total dry weight production (TDW), number of pods (NP), number of ears (NE) and number of seeds (NS) of soybean and barley plants grown on Cambisol and Nitro soil in a greenhouse.

\begin{tabular}{|c|c|c|c|c|c|c|c|c|c|c|c|c|}
\hline \multirow[b]{3}{*}{ Treatment } & \multicolumn{3}{|c|}{........Cambisol....... } & \multicolumn{3}{|c|}{..........Nitisol......... } & \multicolumn{3}{|c|}{..........Cambisol.......... } & \multicolumn{3}{|c|}{............Nitisol............. } \\
\hline & \multicolumn{6}{|c|}{ 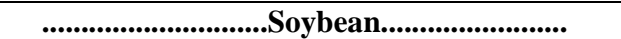 } & \multicolumn{6}{|c|}{ 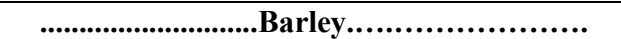 } \\
\hline & TDW & NP & NS & TDW & NP & NS & TDW & NE & NS & TDW & NE & NS \\
\hline t ha $^{-1}$ & $\mathbf{g}$ & & & $\mathbf{g}$ & & & $\mathbf{g}$ & & & $\mathbf{g}$ & & \\
\hline Control & 1.21 & 4 & 6 & 2.08 & 4 & 6 & 0.59 & 0.0 & 0.0 & 1.13 & 0.0 & 0.0 \\
\hline Conventional & 10.52 & 28 & 52 & 12.39 & 30 & 58 & 69.32 & 39 & 613 & 49.60 & 46 & 704 \\
\hline Siltstone -5.0 & 1.67 & 6 & 11 & 2.71 & 6 & 9 & 0.75 & 0.0 & 0.0 & 1.26 & 0.0 & 0,0 \\
\hline Siltstone - 10 & 2.39 & 6 & 12 & 2.27 & 8 & 12 & 0.74 & 0.0 & 0.0 & 1.39 & 0.0 & 0.0 \\
\hline Tephrite - 5.0 & 2.11 & 5 & 9 & 2.46 & 6 & 10 & 0.96 & 0.0 & 0.0 & 1.84 & 1 & 14 \\
\hline Tephrite -10 & 3.40 & 7 & 13 & 2.73 & 7 & 12 & 0.92 & 0.0 & 0.0 & 1.89 & 3 & 36 \\
\hline Olivine Melilitite -5.0 & 5.22 & 16 & 31 & 4.38 & 13 & 23 & 5.08 & 10 & 166 & 10.01 & 8 & 129 \\
\hline Olivine Melilitite - 10 & 6.18 & 22 & 33 & 4.84 & 15 & 27 & 14.95 & 10 & 193 & 17.59 & 13 & 250 \\
\hline Siltstone + Olivine Melilitite -5.0 & 4.79 & 14 & 27 & 3.69 & 11 & 19 & 2.47 & 0.0 & 0.0 & 6.72 & 5 & 91 \\
\hline \multirow[t]{2}{*}{ Siltstone + Olivine Melilitite -10} & 5.35 & 15 & 27 & 5.33 & 17 & 30 & 4.12 & 6 & 44 & 12.96 & 10 & 172 \\
\hline & \multicolumn{12}{|c|}{ F test - Orthogonal contrasts } \\
\hline Control vs Conventional & ** & ** & ** & ** & ** & *** & ** & ** & ** & ** & ** & ** \\
\hline Control vs Silt.5 and Silt. 10 & $*$ & NS & $*$ & NS & NS & NS & NS & NS & NS & NS & NS & NS \\
\hline Control vs Teph.5 and Teph. 10 & ** & NS & * & NS & NS & NS & NS & NS & NS & NS & ** & NS \\
\hline Control vs O. Meli. 5 and O. Meli. 10 & $* *$ & $* *$ & $* *$ & $* *$ & $* *$ & $* *$ & $* *$ & $* *$ & $* *$ & $* *$ & $* *$ & $* *$ \\
\hline Control vs Silt. + O. Meli. 5 and Silt.+ O. Meli.10 & $* *$ & $* *$ & $* *$ & $* *$ & $* *$ & $* *$ & $*$ & $* *$ & NS & $* *$ & $* *$ & $* *$ \\
\hline Silt. 5 and Silt. 10 vs Teph. 5 and Teph. 10 & $*$ & NS & $* *$ & NS & NS & NS & $* *$ & NS & NS & NS & $*$ & $* *$ \\
\hline Silt. 5 and Silt. 10 vs O. Meli. 5 and O. Meli. 10 & $* *$ & $* *$ & $* *$ & $* *$ & $* *$ & $* *$ & $* *$ & NS & $* *$ & $* *$ & $* *$ & $* *$ \\
\hline Teph. 5 and Teph. 10 vs O. Meli.5 and O. Meli. 10 & $* *$ & $* *$ & $* *$ & $* *$ & $* *$ & $* *$ & $* *$ & $* *$ & $* *$ & $* *$ & $* *$ & $* *$ \\
\hline $\begin{array}{l}\text { Teph.5 and Teph.10 vs Silt+O. Meli.5 and Silt+O. } \\
\text { Meli.10 }\end{array}$ & $* *$ & $* *$ & $* *$ & $* *$ & $* *$ & $* *$ & $* *$ & $* *$ & NS & $* *$ & $* *$ & $* *$ \\
\hline Silt. 5 and O. Meli. 5 vs Silt. + O. Meli. 5 & $* *$ & $* *$ & $*$ & NS & NS & NS & $* *$ & NS & $* *$ & $* *$ & NS & NS \\
\hline Silt.10 and O. Meli.10 vs Silt. + O. Meli.10 & $*$ & $*$ & $*$ & $*$ & $* *$ & $* *$ & $* *$ & $* *$ & $* *$ & $* *$ & NS & $*$ \\
\hline Conventional vs Silt.5 and Silt.10 & $* *$ & $* *$ & $* *$ & $* *$ & $* *$ & $* *$ & ** & $* *$ & $* *$ & $* *$ & $* *$ & $* *$ \\
\hline Conventional vs Teph. 5 and Teph.10 & $* *$ & $* *$ & $* *$ & $* *$ & $* *$ & $* *$ & $* *$ & $* *$ & $* *$ & $* *$ & $* *$ & $* *$ \\
\hline Conventional vs O. Meli.5 and O. Meli.10 & $* *$ & $* *$ & $* *$ & $* *$ & $* *$ & $* *$ & $* *$ & $* *$ & $* *$ & $* *$ & $* *$ & $* *$ \\
\hline $\begin{array}{l}\text { Conventional vs Silt.+ O. Meli.5 and Silt.+ O. } \\
\text { Meli.10 }\end{array}$ & $* *$ & $* *$ & $* *$ & $*$ & $*$ & $*$ & $* *$ & $* *$ & $* *$ & $* *$ & $* *$ & $* *$ \\
\hline
\end{tabular}

Silt. (Siltstone); Teph. (Tephrite); O. Meli. (Olivine Melilitite); Silt. + O. Meli. (Siltstone + Olivine Melilitite). NS: Non-significant. ** Significant at $1 \%$ and $* *$ significant at $5 \%$. Source: Authors (2021).

In terms of yield, the better response of soybean and barley plants occurred with powders from olivine melilitite and siltstone + olivine melilitite rocks, in comparison to the control. This may be related to the reduced acidity and the improved fertility of the two soils, providing greater nutrient contribution to them (Table 3 and Figure 1), thus allowing the plants to have access to these nutrients during their different development stages. On the other hand, for siltstone and tephrite, the yield of these plants may have been impaired by low $\mathrm{pH}$ values and high $\mathrm{Al}^{3+}$ contents, which may have been detrimental to them from the beginning of their development until seed production (when it was possible to evaluate), even though there was partial improvement in soil chemical conditions. Specifically for Nitisol, the element $\mathrm{P}$, in addition to acidity, may have been limiting for the low plant response (especially barley) in these treatments (Tables 3 and 4, Figures 1 and 2).

Some rock powders showing little to no response in improving soil fertility and plant yield was also verified by Hanisch et al. (2013), Tavares et al. (2018), Aguilera et al. (2020a) and Marques et al. (2020) when evaluating other rock powders applied on different soils and their contact times with these soils. In this sense, Gotz et al. (2019) and Ramos et al. (2020) attribute this behavior to the low solubility of the nutrients within rock powders, leading to their low release to plants. Nonetheless, most of authors mentioned above verified improvements of these products when combined with an organic source, as also found in this study when combining bovine manure with siltstone, tephrite and with siltstone + olivine melilitite (data not shown).

Regarding the comparisons made only with powders from siltstone and tephrite rocks, the yield of plants tested in these treatments did not differ from each other (Table 4), thereby confirming the previous idea that the acidity of both soils 
tested and their low P content, mainly in the Nitisol (Table 3), were determinant for the low response of plants grown on the two soils subjected to these powders (Table 4 and Figure 5). Possibly, these products need more time to solubilize and release nutrients to the plants. In the siltstone case, this may have been caused by the dominant quartz presence, as previously evidenced when analyzing mineralogical this rock. As for tephrite, it may be related to the low sum of basic oxides when compared to $\mathrm{Al}_{2} \mathrm{O}_{3}$, which possibly maintained or increased soil acidity (Table 2 and Figure 1).

Figure 5. Production of total dry matter (TDM), number of pods (NP), ears (NE) and seeds (NS) by soybean and barley plants.

\section{Soybean}
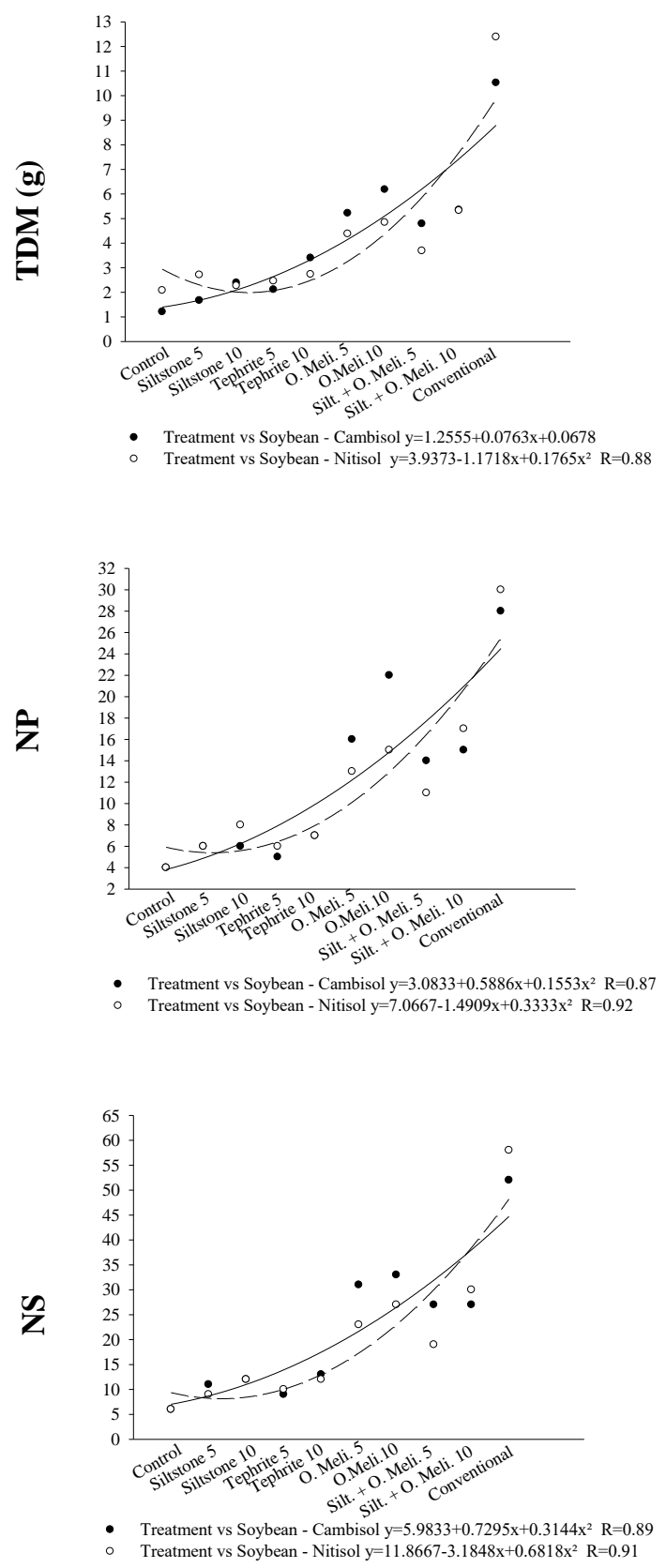

Barley
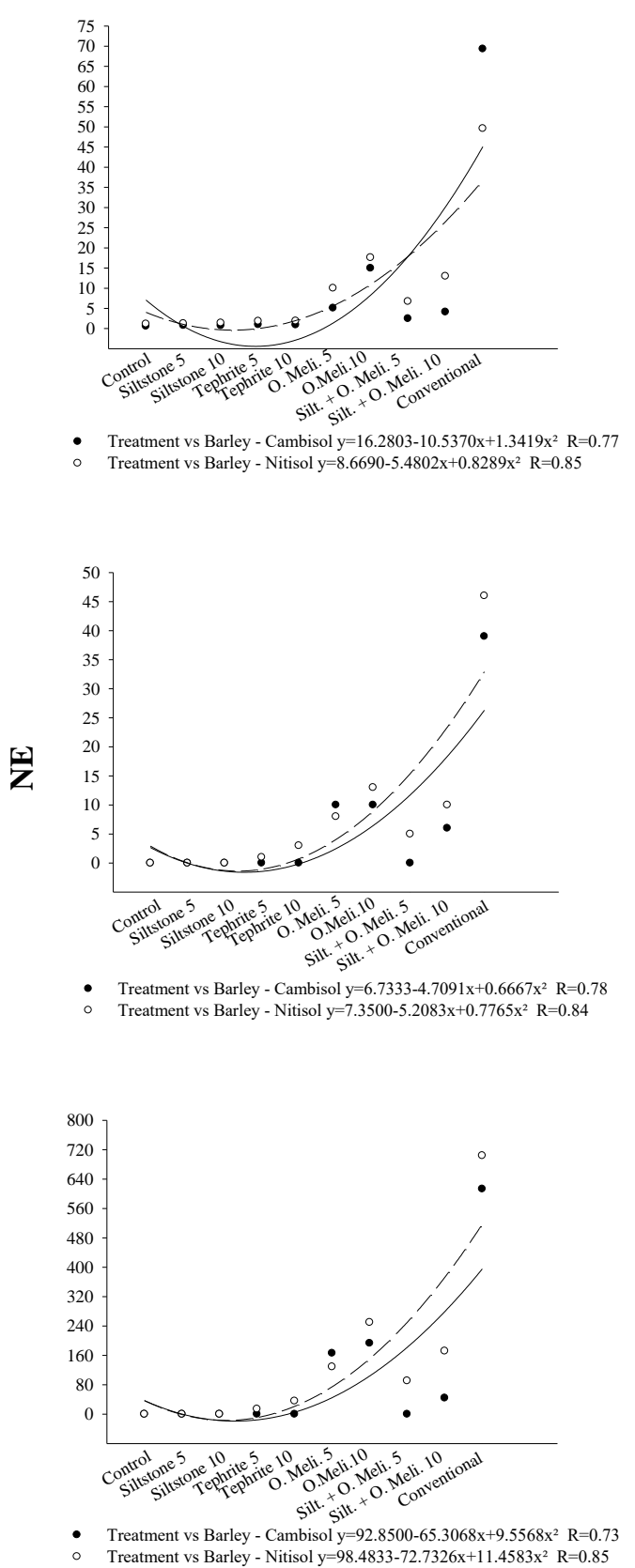

\section{Treatment $\left(\mathrm{t} \mathrm{ha}^{-1}\right)$}

Source: Authors (2021). 
Still on siltstone and tephrite, mixing them with other rocks that are richer in oxides and $\mathrm{P}_{2} \mathrm{O}_{5}$ or with organic sources with faster nutrient release is suggested to improve the final chemical composition of the mixing. This strategy is interesting to consider, as these two rocks have very high $\mathrm{K}_{2} \mathrm{O}$ levels (Table 2), which are important $\mathrm{K}^{+}$sources for both soils and plants alike.

Statistical differences evidenced in comparisons between the powders from siltstone, tephrite, olivine melilitite and siltstone + olivine melilitite rocks are related to the higher yield of plants grown and subjected to these last two powders (Table 4). These results show that olivine melilitite, pure or mixed with another rock, can be an interesting strategy for rebuilding soil fertility over time, since the production of plants tested in this study was kept at high levels, even with the shorter contact time of this rock with the soils (Table 4 and Figure 2). This is due to the presence of minerals in this rock that are less resistant to weathering (Duarte et al., 2013; Oelkers et al., 2018) as well as the higher basic oxides richness (Table 2), which may be potential sources of $\mathrm{Ca}^{2+}, \mathrm{Mg}^{2+}, \mathrm{K}^{+}, \mathrm{P}$ and micronutrients.

The fact of olivine melilitite mixed with siltstone having a better response when compared to the control and the pure powders from siltstone and tephrite rocks may be related to the presence of pyrite and sulfur in the minerals that constitute siltstones (Figure 2). Thus, the dissolution of pyrite may have favored the faster solubilization of the minerals within olivine melilitite and even siltstone, providing increased nutrient content in the soil and increasing plant yield.

However, statistical differences evidenced in the comparisons between the pure powders from siltstone and olivine melilitite and siltstone + olivine melilitite rocks at the two tested doses may be related to the higher production of TDW, pods, ears and seeds recorded on treatments which had these products tested separately. In other words, the sum of plant yield parameters in these treatments exceeded the obtained with combining siltstone and olivine melilitite (Table 4). This may have occurred due to the dilution of nutrients present in the chemical composition of the two rocks after their combination.

Combining these two rocks (1:1 ratio), provided in the final product an increase in $\mathrm{Al}_{2} \mathrm{O}_{3}$ and $\mathrm{SiO}_{2}$ contents, as well as the dilution of $\mathrm{CaO}, \mathrm{MgO}$ and $\mathrm{P}_{2} \mathrm{O}_{5}$ contents and a slight increase in $\mathrm{K}_{2} \mathrm{O}$, when compared to the pure olivine (Table 2). Even so, this combination provided improved soil fertility and increased yield of the two tested crops over the two experiments (Tables 3 and 4, Figures 1 and 2, respectively).

In terms of yield, the best plant responses were obtained in the conventional treatment (Table 4 and Figure 2). This behavior was already expected, as limestone and conventional fertilizers are much more soluble and their release of nutrients into the soil solution is faster, providing their greater availability for plants to absorb and later express their productive potential (Zhang et al., 2019; Vanda-Sebastião et al., 2019). However, it should be considered that improvements in soil fertility and plant yield, notably in the first crop on treatments with powders from olivine melilitite and siltstone + olivine melilitite rocks were substantial, given the low solubility of these rocks when compared to conventional fertilizers (Ribeiro et al., 2020; Manning \& Theodoro, 2020) and the short contact time of these products and the soils. This further reinforces the idea that this rock can be considered as a good SR.

Results of this study are corroborated by those conducted by Melo et al. (2012), Miranda et al. (2018), Pereira et al. (2019), Pereira et al. (2020) Aguilera et al. (2020b), Junior et al. (2020), Marchi et al. (2020) and Nogueira et al. (2021). These authors, even considering that they were evaluating different rock powders (pure or combined with organic sources) and soils, reported substantial increases in basic cations and $\mathrm{P}$, base sum and saturation, and micronutrients as well as their acidity partial correction, also verifying improved soil fertility even in short-term experiments. This indicates that these products can benefit both soils and plants over time when evaluated in adequate conditions to express their agronomic potential, and when their physical, chemical, mineralogical and even petrographic characteristics are all taken into consideration (MAPA, 2016; Gomez et al., 2021; Akinyemi et al., 2021; Ribeiro \& Flores, 2021).

Given the results obtained in this study, it is suggested to evaluate the potential of these rocks, pure or combined, 
associated or not with organic sources in field experiments, in order to assess their effects on improving soil and plant fertility. In addition, evaluate the potential of other rocks from the Lages region or other locations as soil remineralizers for use in agriculture, taking into account current Brazilian legislation (MAPA, 2016).

\section{Conclusions}

Elemental chemical, mineralogical and petrographic analyses performed on rock powders from pure olivine melilitite and tephrite and on the siltstone + olivine melilitite mixing met the requirements for their classification as SR. Fertility on evaluated soils was improved as well as the crop yield was increased by using these products.

In the olivine melilitite and tephrite rocks, petrographic analyses indicated an expressive presence of minerals relatively less resistant to weathering composed by, respectively: olivine, phlogopite, melilitite, cebolite, monticellite, perovskite, aegirine and traces of apatite in the former; and sanidine, aegerine-augite, titanite, nepheline and apatite in the latter. This composition was confirmed by mineralogical analyses via XRD, with additions of vermiculites in the olivine melilitite and of sanidine and analcime in the tephrite. As for siltstone, this same analysis revealed the presence of vermiculites, apatite, pyrite, sanidine, nepheline, pyroxenes and apatite, with quartz predominating.

Olivine melilitite, pure or mixed with siltstone, provided substantial increases in soil fertility and plant yield, hence confirming it as the one with greatest SR potential among tested products. Tephrite also met the requirements for SR classification; however, it had less response when compared to olivine melilitite. Siltstone, in its pure form, does not meet these requirements probably due to excessive quartz content; yet by considering its high sulfur and $\mathrm{K}_{2} \mathrm{O}$ contents, it can be used mixed with other rock powders.

Bearing in mind that all tested products were applied in nature, with no association with manures, biosolubilizers or pre-treatments to increase their dissolution, the results here obtained show that rock powders have potential for act as nutrient sources and/or to be registered as SR.

\section{Acknowledgments}

To the company Dinamisa S.A. and Coordination for the Improvement of Higher Education Personnel (CAPES [in Portuguese] - Brazil: PROAP/AUXPE) for financial support. The authors would like to thank their friends, colleagues and professors who helped directly and, or, indirectly in the different phases of conducting this research to obtain the results that gave rise to this study.

\section{References}

Aguilera, J. G., Zuffo, A. M., Ratke, R. F., Trento, A. C. S., Lima, R. E., Gris, G. A., Morais, K. A. D., Silva, J. X. \& Martins, W. C. (2020a). Influencia de dosis de polvo de basalto sobre cultivares de soya. Research, Society and Development, 9, 1-22. http://dx.doi.org/10.33448/rsd-v9i7.3974

Aguilera, J.G., Goes, R. J., Zuffo, A. M., Ratke, R.F., Silva, N. P., Godoy, M. L. \& Erharter, J. F. N. (2020b) Residual effect of rock dust doses after two years of application in maize. Agricultura 4.0, 1, 97-104. https://doi.org/10.46420/9786599064159cap6

Akinyemi, S.A., Nyakuma, B.B., Jauro, A., Adebayo, O.F., Olaolorun, O.A., Adegoke, A.K., Aturamu, A.O., Adetunji, A., Gitari, W. M. \& Mudzielwana, R. (2021) Mineralogy, physicochemical and oxidative thermal analyses of cretaceous coals from the Benue Trough, Nigeria. Energy Geoscience. 2, 129-135. https://doi.org/10.1016/j.engeos.2020.07.001

Alovisi, A. M. T., Taques, M. M., Alovisi, A. A., Tokura, L. K., Silva, J. A. M. \& Cassol, C. J. (2020a). Rochagem como alternativa sustentável para a fertilização de solos. Revista Gestão e Sustentabilidade Ambiental, 9, 918-932.

Alovisi, A. M. T., Cassol, C. J., Nascimento, J. S., Soares, N. B., Junior, I. R. S., Da Silva, R. S. \& Da Silva, J. A. M. (2020). Soil factors affecting phosphorus adsorption in soils of the Cerrado, Brazil. Geoderma Regional, v.22, e00298, 1-7. https://doi.org/10.1016/j.geodrs.2020.e00298

Basak, B. B., Sarkar, B. \& Naidu, R. (2020). Environmentally safe release of plant available potassium and micronutrients from organically amended rock mineral powder. Environmental Geochemistry and Health, 43, 3273-3286. https://doi.org/10.1007/s10653-020-00677-1. 
Basak, B. B., Sarkar, B., Biswas, D.R., Sarkar, S., Sanderson, P. \& Naidu, R. (2017). Bio-Intervention of Naturally Occurring Silicate Minerals for Alternative Source of Potassium: Challenges and Opportunities. Elsevier, Advances in Agronomy, 141, 115-145. https://doi.org/10.1016/bs.agron.2016.10.016

Brindley, G. W. \& Brown, G. (1980). Cristal structures of clay minerals and their X ray identification. Mineralogical Society.

Casaroli, D. \& Lier, Q. J. van. Critérios para determinação da capacidade de vaso. Revista Brasileira de Ciência do Solo, 32, 59-66, 2008. https://doi.org/10.1590/S0100-06832008000100007

Comissão de Química e Fertilidade do Solo dos Estados do Rio Grande do Sul e de Santa Catarina - CQFS-RS/SC. (2016). Manual de calagem e adubação para os Estados do Rio Grande do Sul e de Santa Catarina.

Cunha, G. O. M., Almeida, J. A., Souza, C. A. \& Ernani, P. R. (2019a). Nutritional efficiency and nutrient accumulation of maize cultivated in soils with high Al-KCl content. Journal of Agricultural Science, 1,107-123. https://doi.org/10.5539/jas.v11n16p107

Duarte, W. M., Mafra, A. L., Foresti, M. M., Piccolla, C. D. \& Almeida, J. A. (2013). Potencial de olivina melilitito, granito e sienito na disponibilização de potássio em solos. Revista de Ciências Agroveterinárias, 12, 68-77.

Dunworth, E. A. \& Wilson, M. (1998). Olivine melilitites of the SW German Tertiary Volcanic Province: Mineralogy and Petrogenesis. Journal of Petrology, 39, 1805-1836. https://doi.org/10.1093/petroj/39.10.1805

Empresa Brasileira de Pesquisa Agropecuária - EMBRAPA. (2009). Manual de análises químicas de solos, plantas e fertilizantes.

Empresa Brasileira de Pesquisa Agropecuária - EMBRAPA. (2017). Manual de métodos de análise de solo.

Fazio, G., Guimarães, E. M., Walde, D. W. G., Do Carmo, D. A., Adorno, R. R., Vieira, L. C., Denezine, M., Da Silva, C. B., De Godoy, H. V., Borges, P. C. \& Pinho, D. (2019). Mineralogical and Chemical composition of Ediacaran-Cambrian pelitic rocks of the Tamengo and Guaicurus formations, (Corumbá Group- MS, Brazil): stratigraphic positioning and paleoenvironmental interpretations. Journal of South American Earth Sciences, 90, 487-503. https://doi.org/10.1016/j.jsames.2018.11.025

Ferreira, D. F. (2014). Sisvar: a guide for its Bootstrap procedures in multiple comparisons. Ciência e Agrotecnologia, 38, 109-112. https://doi.org/10.1590/S1413-70542014000200001

Ferreira, E. R. N. C., Almeida, J. A. \& Mafra, A. L. (2009). Pó de basalto, desenvolvimento e nutrição do feijão comum (Phaseolus vulgaris) e propriedades químicas de um Cambisol Húmico. Revista de Ciências Agroveterinárias, 8, 111-121.

Gómez, L. P., Ramos, C. G., Oliveira, M. L. S. \& Silva, L.F.O. (2021). Release kinetics of multinutrients from volcanic rock mining by-products: evidences for their use as a soil remineralizer. Journal of Cleaner Production, 279, 123668. https://doi.org/10.1016/j.jclepro.2020.123668

Gotz, L. F., Castamann, A., Piovesan, F., Anzolin, B. L., Herek, T. A., Mikoanski, W. M. \& Rita, Y. L. (2019). Use of rock powder associated with bovine manure in Latossolo Vermelho cultivated with wheat. Revista Brasileira de Agropecuária Sustentável (RBAS), 9, 131-139. https://doi.org/10.21206/rbas.v9i2.3464

Goulding, K. W. T. (2016). Soil acidification and the importance of liming agricultural soils with particular reference to the United Kingdom. Soil Use and Management, 32, 390-999. https://doi.org/10.1111/sum.12270

Hanisch, A.L., Fonseca, J. A., Junior, A. A. B. \& Spagnoli, E. (2013). Efeito de pó de basalto no solo e em culturas anuais durante quatro safras, em sistema de plantio direto. Revista Brasileira de Agropecuária Sustentável, 3, 100-107. https://doi.org/10.21206/rbas.v3i2.224

Jackson, M. L. (1965). Soil Chemical Analysis. (2a ed.) Madison: Department of Soil Science- University of Wisconsin. Advanced Course. 991p. (Mimeografado).

Janney, P. E., Le Roex, A. P., Carlson, R. W. \& Viljoen, K. S. A. (2002). Chemical and multi-isotope study of the Western Cape olivine melilitite province, south Africa: implications for the sources of kimberlites and the origin of the HIMU signature in Africa. Journal of Petrology, 43, 2339-2370. https://doi.org/10.1093/petrology/43.12.2339

Jiang, J., Wang, Y. P., Yu, M., Cao. N. \& Yan, J. (2018). Soil organic matter is important for acid buffering and reducing aluminum leaching from acidic forest soils. Chemical Geology, 501, 86-94. https://doi.org/10.1016/j.chemgeo.2018.10.009

Júnior, J. J. A., Lazarini, E., Smiljanic, K. B. A., Simon, G. A., Matos, F. S. A., Barbosa, U. R., Silva, V. J. A., Mirand, B. C. \& Silva, A. R. (2020). Análise das variáveis tecnológicas na cultura da soja (Glycine max) com utilização de remineralizador de solo como fertilizante. Brazilian Journal of Development, 6 , 56835-56847. https://doi.org/10.34117/bjdv6n8-190

Longo, A. E. D. V., Almeida, J. A., Cunha, G. O. M. \& Lazzari, C. J. R. (2021). Mineralogy and genesis of soils developed from ultrabasic and alcaline rocks of Lages Alcaline Complex, Brazil. Revista Brasileira de Ciências Agrárias, 16, 1-12. https://doi.org/10.5039/agraria.v16i3a9054

Lopes, R. P. \& Ulbrich, M. N. C. (2015). Geochemistry of the alkaline volcanic-subvolcanic rocks of the Fernando de Noronha Archipelago, southern Atlantic Ocean. Brazilian Journal of Geology, 45, 307-333. https://doi.org/10.1590/23174889201500020009

Lungu, O. I. M. \& Dynoodt, R. F. P. (2008). Acidification from long-term use urea and its effect on selected soil properties. African Journal of Food Agriculture Nutrition and Development, 8, 63-76. https://doi.org/10.4314/AJFAND.V8I1.19180

Manning, D. A. C. \& Theodoro, S. H. (2020). Enabling food security through use of local rocks and minerals. The Extractive Industries and Society, 7, 480487. https://doi.org/10.1016/j.exis.2018.11.002

Ministério da Agricultura, Pecuária e Abastecimento - MAPA. (2016). Instrução Normativa No 5, de 10 de março de 2016. https://www.gov.br/agricultura/ptbr/assuntos/insumos-agropecuarios/insumos-agricolas/fertilizantes/legislacao/in-5-de-10-3-16-remineralizadores-e-substratos-para-plantas.pdf 
Marchi, G., Guelfi-Silva, D. R., Malaquias, J. V., Guilherme, L. R. G., Spehar, C. R. \& Martins, E. S. (2020). Solubility and availability of micronutrients extracted from silicate agrominerals. Pesquisa Agropecuária Brasileira, 55, 1-12. https://doi.org/10.1590/S1678-3921.pab2020.v55.00807

Marques, M. L. S., Jesus, J. M. I., Santos, W. M., Silva, J. W. G., Martins, A. L. S. \& Marques, V. S. (2020). Agronomic efficiency of fertilizers based on humus, rock powder, and mineral on soybean yield in Paraguay-PY. Revista de Agricultura Neotropical, 7, 90-96. https://doi.org/10.32404/rean.v7i3.4364

Martins, V., Gonçalves, A. S. F., Marchi, G., Guilherme, L. R. G. \& Martins, E. S. (2015). Solubilização de potássio em misturas de verdete e calcário tratadas termoquimicamente. Pesquisa Agropecuária Tropical, 45, 66-72.

Melo, V. F., Uchôa, S. C. P., Dias, F. O. \& Barbosa, G. F. (2012). Doses de basalto moído nas propriedades químicas de um Latossolo Amarelo distrófico da savana de Roraima. Acta Amazônica, 42, 471-476. https://doi.org/10.1590/S0044-59672012000400004

Miranda, C. C. B., Florentino, L. A., De Rezende, A. V., Nogueira, D. A., Leite, R. F. \& Naves, L. P. (2018). Desenvolvimento de Urochloa brizantha adubada com fonolito e inoculada com bactérias diazotróficas solubilizadoras de potássio. Sociedade de Ciências Agrárias de Portugal, 41(3), 625-632. https://doi.org/10.19084/RCA17011

Mumbach, G. L.; Gatiboni, L. C.; Dall'Orsoletta, D. J.; Schmitt, D. E.; Pessotto, P. P. \&Oliveira, C. M. B. (2020). Phosphorus extraction with soil test methods affected by soil P sorption capacity. Journal of Soil Science and Plant Nutrition, 20, 1882-1890. https://doi.org/10.1007/s42729-020-00259-1

Murphy, J. \& Riley, J. P. (1962). A modified single solution method for the determination of phosphate in natural Waters. Analytica Chimica Acta, 27, 31-36. https://doi.org/10.1016/S0003-2670(00)88444-5

Nogueira, T. A. R., Miranda, B. G., Jalal, A., Lessa, L. G. F., Filho, M. C. M. T., Marcante, N. C., Abreu-Junior, C. H., Jani, A. D., Capra, G. F., Moreira, A. \& Martins, E. S. (2021). Nepheline syenite and phonolite as alternative potassium sources for maize. Agronomy, 11, 7, 1385. https://doi.org/10.3390/agronomy11071385

Oelkers, E. H., Declersq, J., Saldi, G. D., Gislason, S. R. \& Schott, J. (2018). Olivine dissolution rates: A critical review. Chemical Geology, 500, 1-19. https://doi.org/10.1016/j.chemgeo.2018.10.008

Pereira, M. B., Véras, M. L. M., De Lima, N. R., Dos Santos, L. G. \& Dias, T. J. (2019). Bovine manure and rock powder and their influences on the chemical characteristics of a Latossolo soil type (Yellow Oxisols) under butter kale (Brassica oleracea L. var. acephala) cultivation. Revista Colombiana de Ciências Hortícolas, 12, 448-457. https://doi.org/10.17584/rcch.2019vl3i3.10597

Pereira, M. B., Dias, T. J., Lima, N. R., Justino, E. S., Oliveira, D. S. \&Martins-Veras, M. L. (2020). Plant growth and yield of butter kale (Brassica oleracea L. var. acephala), as influenced by the combined application of bovine manure and rock powder. Acta Agronômica, 69, 38-45. https://doi.org/10.15446/acag.v69n1.75174

Ramos, C. G., De Medeiros, D. D. S., Gomez, L., Oliveira, L. F. S., Schneider, I. A. H. \& Kautzmann, R. M. (2019). Evaluation of soil Re-mineralizer from by-product of volcanic rock mining: experimental proof using black oats and maize crops. Natural Resources Research, 29 , 1583-1600. https://doi.org/10.1007/s11053-019-09529-x

Ramos, C. G., Hower, J. C., Blanco, E., Oliveira, M. L. S. \& Theodoro, S. H. (2021). Possibilities of using silicate rock powder: An overview. Geoscience Frontiers, 1-11. https://doi.org/10.1016/j.gsf.2021.101185

Renforth, P., Pogge Von Strandmann, P. A. E. \& Henderson, G. M. (2015). The dissolution of olivine added to soil: implications for enhanced weathering. Applied Geochemistry, 61, 109-118. https://doi.org/10.1016/j.apgeochem.2015.05.016

Ribeiro, J. \& Flores, D. (2021). Occurrence, leaching, andmobility ofmajor and trace elements in a coal mining waste dump: the case of Douro Coalfield, Portugal. Energy Geoscience, 2 (2), 121-128. https://doi.org/10.1016/j.engeos.2020.09.005.

Souza, F. N. S., De Oliveira, C. G., Martins, E. S. \& Alves, J. M. (2017). Efeitos condicionador nutricional de um remineralizador de solos obtido de resíduos de mineração. Revista Agri-Environmental Sciences, 3, 1-12.

Streckeisen, A. L. (1978). IUGS Subcommission on the Systematics of Igneous Rocks. Classification and nomenclature of volcanic rocks, lamprophyres, carbonatites and melilitite rocks. Recommendations and Suggestions. Neues Jahrbuch für Mineralogie, 141,1 - 14.

Tavares, L. F., De Carvalho, A. M. X., Camargo, L. G. B., Pereira, S. G. F. \& Cardoso, I. M. (2018). Nutrients release from powder phonolite mediated by bioweathering actions. International Journal of Recycling of Organic Waste in Agriculture, 7, 89-98. https://doi.org/10.1007/s40093-018-0194-X

Tedesco, M. J., Gianello, C., Bissani, C. A., Bohnen, H. \& Volkweiss, S. J. (1995). Análise de solo plantas e outros materiais. (2a ed.), Universidade Federal do Rio Grande do Sul. (Boletim técnico, 5).

Theodoro, S. H., Medeiros, F.P., Ianniruberto, M. \& Jacobson, T. K. B. (2020). Soil remineralization and recovery of degraded areas: an experience in the tropical region. Journal of South American Earth Sciences, 107, 103014 https://doi.org/10.1016/j.jsames.2020.103014.

Vanda-Sebastião, J. S., Ferrer-Castilho, A., Costa-Quizembe, J. \& Carvalho-Zacarias, E. F. (2019). Aplicação de doses crescentes de calcário por incubação nos solos da chianga-huambo, Angola. Revista Cubana de Química, 31, 258-282.

Whittig, L. D. \& Allardice, W. R. (1986). X-ray diffraction techniques. In: Klute, A. (ed). Methods of soil analysis. Part 1. Physical and mineralogical methods. (2a ed.), Soil Science Society of America, 331p.

Zhang, Y., Zhang, S., Wang, R., Cai, J., Zhang, Y., LI, H., Huang, S. \& Jiang, Y. (2016). Impacts of fertilization practices on pH and the pH buffering capacity of calcareous soil. Soil Science Plant Nutrition, 62, 432-439. https://doi.org/10.1080/00380768.2016.1226685 